\title{
Gıda Sektöründe İstatistiksel Proses Kontrolü: Endüstriyel Ekmek Üretim Tesisi Uygulaması
}

\author{
İbrahim Zeki AKYURT ${ }^{1 *}$ \\ ${ }^{1}$ İstanbul Üniversitesi, İşletme Fakültesi, Üretim ABD, İstanbul/Türkiye \\ Geliş / Received: 16/08/2019, Kabul / Accepted: 20/02/2020
}

\begin{abstract}
$\ddot{\mathbf{O} z}$
Günümüz zorlu rekabet ortamında işletmeler, varlıklarını sürdürebilmek için kalite ve kontrol faaliyetlerine önem vermektedirler. Kalite kontrol tekniklerinden biri olan istatistiksel süreç kontrolü, üretim ve hizmet süreçlerinin ölçülebilir veriler yardımıyla istenilen düzeye çekilmesinde önemli bir rol oynamaktadır. Bu çalışmada, endüstriyel ekmek üretimi yapan bir işletmenin üç fabrikasındaki 10 hatta üretilebilen 300 gram ambalajsız normal ekmek ürünü için istatistiksel süreç kontrol şemaları kullanılarak üretim hatları incelenmiştir. Her hatta pişirme sürecinden sonra örneklem alınmış ve pişmiş ürün gramajı ölçülmüştür. Hatların kendi içerisinde kontrol altında olup olmadığı kalite kontrol şemaları yardımıyla incelenmiştir. Ayrıca fabrikalar ve hatlar arasında istatistiksel olarak anlamlı bir ilişki olup olmadığı için varyans analizi (ANOVA) uygulanmıştır. Kontrol dışındaki süreçlerde hataların nedeni araştırılarak hangi tedbirler alınması gerektiği tespit edilmiştir.
\end{abstract}

Anahtar Kelimeler: Kalite kontrolü, Shewhart kontrol şeması, varyans analizi, endüstriyel firın

\begin{abstract}
Statistical Process Control in Food Sector: Industrial Bread Production Plant Application Abstract

Business organizations in today's challenging environment of competition, place emphasis on quality and control processes to sustain their existence. Statistical process control of which is one of the quality control techniques, initiates an essential role in the adjustment of production and service processes. In this study, 10 production lines of an industrial bread manufacturing company's factories has been investigated with the statictical process control chart. In the three factories, the statistical control chart has been used in the production process of 300 gr. bread. In every line, a sample has been collected after every baking process and grammage has been measured. Within every line, line control has been examined with quality control chart. One way variance analysis (ANOVA) has been applied to study the relationship among factories and lines. Out of control processes, the root basis of errors were investigated to set forth further precautions.
\end{abstract}

Keywords: Quality control, Shewhart control charts, ANOVA, Industrial bakery

*Sorumlu Yazar: akyurt@istanbul.edu.tr 


\section{Giriş}

Günümüzde kalite kontrol sadece karlılığa değil aynı zamanda verimlilik ve kalite sorunlarına başarılı çözümler getirmiştir (Ertuğrul, 2004). Aynı zamanda işletmelerin kaliteyi koruması, geliştirmesi, tüketici istek ve gereksinimlerini en ekonomik seviyede karşılamak için bir dizi süreçtir (Kasa, 1982; Yatk1n, 2003; Özdamar, 2007). İstenilen kalitede ürün üretmek için kalite kontrol faaliyetleri üretim birimlerinde önemli bir yer tutar (Baskan, 1997; Ertuğrul ve Karakaşoğlu, 2006). İstatiksel proses (süreç) kontrolü (IIPK), kaliteyi ölçmek için istatistiksel teknikleri kullanan bir tekniktir (Rowlands ve Wang, 2000). Literatürde çeşitli alanlarda kontrol yaklaşımları kullanılarak başarılı çalışmalar yapılmıştır. Bunlardan bazıları şöyledir: ürün veya hizmetlerin kalite seviyelerini arttırmaya yönelik kalite araçlarından kontrol grafiklerinin bir üretim işletmesinde uygulanması (Ertuğrul ve Özçil, 2015), web ürünlerinin u şemaları ile istatiksel proses kontrolü (Dweiri vd., 2015), bio-dizel üretimindeki prosesin izlenilmesi için kontrol şemalarının kullanımı (Sales vd., 2016), kalitenin iyileştirilmesi amacıyla havacılık ve uzay sektöründe istatiksel kalite kontrol uygulanması (Yılmaz ve Erzöz, 2017), akı1lı üretim teknolojilerini kullanan bir işletmede büyük veri analizi ve proses kontrolü uygulaması (He and Wang, 2018), düz dişlilerdeki aşınma ve kırıkların tespiti (Maraş ve Arslan, 2018), sicak dövme ve talaşlı işlem yoluyla makine parçası imal eden bir firmada kalite kontrol (Şengül ve Şengül, 2018), ve kontrol çizelgelerinin sağlık alanında kullanımı (Doğan ve Doğan, 2019).

Üretim aşamasında sürecin kalite kontrolü için kullanılan çok sayıda istatistiksel teknik vardır. Bunlardan bazıları; histogram, kontrol tablosu, pareto analizi, hata yoğunluk diyagramı ve kontrol şemalarıdır. Kontrol şemaları (diyagram), istatistiksel proses kontrolünde sıkça kullanılan araçlardan biri olup ilk olarak 1924 yılında Shewhart tarafından kullanıldığından onun adını almaktadır. Hem ölçülebilir hem de ölçülemeyen kalite karakteristikleri için varyasyonun varlığının tespitine ve türünü görmeye fayda sağlamaktadır. Bunun yanında bir üretim sürecinin kontrol altında olup olmadığının kararını vermeye yardımcı olmaktadır. Kontrol dışı bir durumun olduğunu tespit etmekte oldukça kullanışlı bir araçtır. Süreç kontrol dışına çıktığında hızlı bir şekilde uyarı vererek, kontrol dışına çıkma nedenlerini araştırmak ve problemi çözmek için yardımcı olmaktadır.

Kontrol şemalarının tanıtılmasından bu yana birçok uygulamada kullanılmıştır (Ertuğrul ve Karakaşoğlu, 2006). Elevli ve Behdioğlu (2006), 1-2. grup kömürlere ait kalorifik değer ölçümlerinin istatistiksel olarak kontrol altında olup olmadığı $\bar{X}-R$ kontrol şemaları kullanarak tespit etmişlerdir. Ayrıca Varyans Analizi (ANOVA) ile kontrol diyagramları sonuçlarını incelemişlerdir. Zeyveli ve Selalmaz (2008), istatistiksel süreç kontrol tekniklerini zincir imalatı yapan bir işletmede kullanmışlardır. Yıldırım ve Karaca (2013), yangın ve gaz algılama sistemlerinin üretimini yapan bir işletmede istatistiksel proses kontrol tekniklerini uygulamışlardır. Soysal ve Boran (2015), Bulanık $\bar{X}-R$ kontrol diyagramları yardımıyla sürecin kontrol altında olup olmadığını bularak, bulanık spesifikasyon limitleri ile sürecin yeterlilik indislerini hesaplanmışlardır. Arslan (2017), Türkiye'de faaliyet gösteren iki bakır konsantre tesisinden alınan konsantre bakır tenör değerleri için $\bar{X}-R$ kontrol şeması kullanmıştır. $\mathrm{Fu}$ vd. (2017), kömür hazırlamada anahtar bir gösterge olan temiz kömür külü içeriğinin izlenmesi için Shewhart 
kontrol şeması kullanmıştır. Çolak vd. (2018), gri dökme demir örneklemi için bulanık $\bar{X}-$ $R$ kontrol şemaları kullanmışlardır. Bunun yanı sıra gıda sektöründe de istatistiksel proses kontrolü gıda sektöründe de bir çok çalışmada kullanılmıştır (Lim, Antony ve Albliwi, 2014).

İnsanlık tarihi kadar eski olan ekmek, talebin artması ile birlikte kitle üretimi yapılan fabrikalarda üretilmeye başlanmıştır. Özellikle nüfus hızındaki artışa paralel artan ekmek ihtiyac1, klasik anlamda üretim yapan artizan firınların yerine hızlı ve yüksek adetlerde üretim yapan sürekli imalat fabrikalarının kurulmasına neden olmuştur. Türkiye'de en çok tüketilen ekmek çeşidi beyaz ekmektir. Bunun yanı sıra Türk Gida Kodeksi Ekmek ve Ekmek Çeşitleri Tebliği'nde ambalajsız piyasaya sürülen ekmeklerin gramaj1 belirtilmektedir. $\mathrm{Bu}$ tebliğe göre belirtilen gramajdaki ekmeklerin “_\%2" tolerans değerine uyması beklenmektedir. Ekmek gramaj1, izin verilen kanuni sınırların eksi yönde olmasının yanı sıra, artı yönde yükseğe çıktığı takdirde yüksek hacimli kitlesel üretim yapan endüstriyel firınlar için bir dezavantaj olmaktadır. Ekmek başına oluşan fazlalıklar, direkt hammadde kullanım oranını arttırdığından dip toplamda maliyetlerde yükselme meydana gelmektedir. Endüstriyel ekmek üreticileri bir yandan kanuni sınırlara uymakla yükümlü olduklarından bir yandan da maliyetleri arttırmamak istediklerinden ekmek gramajının üzerine yoğunlaşmak akılcı bir yaklaşım olmaktadır. Fakat ekmek üretiminde kullanılan mayanın canlı bir organizma olmas1, üretim sürecindeki ekmeğin fiziksel ve kimyasal süreçlerinin tüm üretim boyunca devam etmesi gramaj kontrolünü daha da zor duruma sokmaktadır.
$\mathrm{Bu}$ çalışmada, endüstriyel ekmek üretim sürecine odaklanılmış ve yukarıdaki sebepler nedeniyle kalite karakteristiği olarak ekmek adedinin gramajı seçilmiştir (Gr/adet). Bunun yanı sıra hamur yoğurma süreciyle başlayıp pişirme ile son bulan üretim süreci boyunca ürüne etkileyen faktörler tespit edilmiştir. $\mathrm{Bu}$ doğrultuda İstanbul'da faaliyet gösteren endüstriyel ekmek üretim işletmesinin farklı 3 fabrikasında üretilen ambalajsız 300 gr. normal beyaz ekmek dikkate alınmıştır. Örneklem; periyodik şekilde, belli bir saatin son beş ekmeği alınarak yapılmıştır. Fabrikanın kendi içerisindeki varyasyon incelenmiş, fabrikalar arası ekmek gramajlarında anlamlı bir fark olup olmadığ 1 belirtilmiştir. Ayrıca ekmek gramaj farklarının sebebi incelenmiş ve giderilmesi için çözüm önerileri sunulmuştur. Proses kontrolü olarak $\bar{X}-R$ kontrol şeması kullanılmıştır.

\section{2. İstatistiksel Süreç Kontrolü ve Kontrol Şemaları}

Süreç (proses) kontrolü ile üretim sırasında diş etkenlerin neden olduğu kalite sorunlarının geciktirilmeden incelenip değerlendirilmesi böylece doğabilecek zararların önlenerek verimliliğin en üst düzeye tutulması amaçlanmıştır.

İstatistiksel süreç kontrolü bir mamul ya da hizmet üretilirken standartların korunması için ölçümler yapılmasını ve duruma göre düzeltici önlemler alınmasını gerektirir (Heizer ve Render, 2017). İstatistiksel süreç kontrolü özetle zaman içinde süreçte yaşanan değişkenliği takip etme ve azaltma işidir. $\mathrm{Bu}$ değişkenlik 1920lerde Walter A. Shewhart tarafından varyasyon olarak adlandırılmıştır. Shewhart'a göre varyasyon iki türlüdür. Bunlar doğal (genel) varyasyon ve tanımlanabilen (özel) varyasyondur. Üretim 
süreci ne kadar iyi tasarlansa da içerisinde doğal varyasyon barındırır. Doğal varyasyon, birçok küçük, temelde kaçınılmaz nedenlerin kümülatif etkisidir. Sadece doğal varyasyonun olduğu bir süreç için süreç istatistiksel olarak kontrol altındadır denmektedir. Tanımlanabilen varyasyonun sebebi ise ayarsız veya yanlış kontrol edilen makineler, operatör hataları veya yanlış hammadde olabilir. Dolayısıyla süreçteki tanımlanabilen varyasyonun varlığında süreç kontrol altında değildir. $\mathrm{Bu}$ noktada istatistiksel süreç kontrolü, tanımlanabilen (özel) varyasyonu anında tespit ederek, kusurlu üretimin çoğalmadan hataya karşı önlem alınmasını ve giderilmesini sağlar. Kontrol şemaları da bu amaç için yaygın olarak kullanılan çevrimiçi bir süreç izleme tekniğidir (Montgomery, 2009). Bir üretim prosesinin kararlılığını, başka bir deyişle varyasyonunu izlemenin en iyi yolu kontrol diyagramlarını kullanmaktır (Baray, 2006). Kontrol şemaları iki türde sınıflandırılır. Bunlar ölçülebilen özellikler için ve ölçülemeyen özellikler için kontrol şemalarıdır. Ölçülebilen özellikler için kontrol şemalarında ,kalite karakteristiği ölçülebilir ve sonucu bir sayı ile ifade edilir. $\bar{X}$ kontrol şeması, merkezi eğilimi kontrol etmek için en yaygın kullanılan bu türde şemadır. $\bar{X}$ kontrol şeması ile birlikte süreçteki varyasyonun tespiti için örnek aralığını (R) veya örnek standart sapmasını gösteren şemalar (s) da birlikte kullanılır ve iki ifadenin birlikte kullanımı ile anılır. $\bar{X}-R$ Kontrol şemasında, $\bar{X}$ grafiğinde ortalamalar, $\mathrm{R}$ grafiğginde "aralıklar" bulunur. $\bar{X}-R$ Kontrol şeması, "Xbar-R Kontrol şeması" şeklinde de ifade edilebilir. İki grafikte de yatay eksende farklı zamanlarda alınmış numunelere örneklere yer verilir. Dikey eksende ise $\bar{X}$ tipi grafikte merkezden geçen, yatay eksene paralel hat arzulanan standart ölçüyü, R tipi grafikte kabul edilebilir aralığı gösterir ve
"Orta Çizgi - CL" olarak adlandırılır. Merkeze, orta çizgiye, ilaveten iki yatay paralel hat daha bulunur (üst ve alt kontrol limitleri-upper and lower control limits-UCL ve LCL). $\mathrm{Bu}$ çizgiler değişkenliğin büyüklüğünü ifade için kullanılır. Önceki verilere bakılarak belirlenen bu kontrol limitleri haricine çıkan numunelerin varlığı süreçte bir problemin mevcut olduğunu gösterir. İstatiksel süreç kontrolünde $\bar{X}-R$ Kontrol şeması ortalama (Sample Mean) ve aralık değerlerinden (Sample Range) elde edilen 2 grafikten oluşur. Bunlardan " $\bar{X}$ " (Sample Mean) her bir alt grubun ortalamas1 alınarak zamana bağlı olarak çizilmiştir ve her bir örneklemin ortalamasının zamana bağlı değişimini yani yığılmanın zamana bağlı değişimini göstermektedir. " $R$ " grafiği ise her bir alt grubun en büyük ve en küçük değerleri arasında fark alınarak elde edilen verilerle çizilmiştir ve her bir örneğin kendi içindeki aralık değerlerinin zamana bağlı değişimini yani yayılmanın zamana bağlı değişimini göstermektedir.

$\bar{X}$ kontrol şemasının formülü;

Orta Çizgi $(C L)=\overline{\bar{X}}$

Alt Kontrol Limiti $(L C L)=\overline{\bar{X}}-A_{2} \bar{R}$

Üst Kontrol Limiti $(U C L)=\overline{\bar{X}}+A_{2} \bar{R}$

R kontrol şemasının formülü;

Orta Çizgi $(C L)=\bar{R}$

Alt Kontrol Limiti $(L C L)=D_{3} \bar{R}$

Üst Kontrol Limiti $(U C L)=D_{4} \bar{R}$

şeklindedir (Montgomery, 2009). 


\section{Uygulama}

$\mathrm{Bu}$ çalışmada, İstanbul'un üç farklı noktasında ekmek fabrikası bulunan bir işletmenin tüm fabrikalarının üretim hatları incelenmiş ve iyileştirme önerileri sunulmuştur.

Şekil 1'de işletmenin İstanbul'da 300 gram normal ekmek satış rakamları kullanılarak ARCGIS tarafından yoğunluk haritası oluşturulmuştur. Sultangazi, Ümraniye ve Küçükçekmece normal ekmek satışın en yüksek olduğu ilçelerdir.

Şekil 2'deki süreç şemasından da görüldüğü üzere her hat, un çekme prosesi ile başlayıp kasalama veya paketleme prosesiyle son bulmaktadır. Kontrol 1'de el ile hamur gramaj kontrolü yapılmaktadır. Eğer gramaj istenilen düzeyde değilse bu hamur yoğrulmaya gönderilerek Kes-Tarta girmektedir. Kontrol 2 ve Kontrol 3 noktalarında el veya sopa ile toplama işlemi gerçekleşmektedir. Buralarda toplanan fireler tekrar kazan fermantasyonu için hamur yoğurma prosesine gönderilmektedir.

Bazı fabrikalarda fotoselli kontrol olmasina rağmen gramaj kontrolü veya şekil bozukluğu kontrolü yapılamamaktadır. Sadece çift gelen hamurlar sensor yardımıyla ayrılmaktadır.

Fabrika 1 (FB1): Toplam 5 hattan oluşup 1. 2. ve 3. hatlarda 300 gr beyaz ekmek üretilmektedir.

Fabrika 2 (FB2): Toplam 6 hattan oluşup 1., 2., 3., 4., 5. ve 6 hatlarda 300 gr beyaz ekmek üretilmektedir.

Fabrika 3 (FB3): Toplam 3 hattan oluşup sadece 1. hatta 300 gr beyaz ekmek üretilebilmektedir.

Çalışmadaki tüm analizlerde MINITAB yazılımı ve yazılımın sonuç tabloları kullanılmıştır.

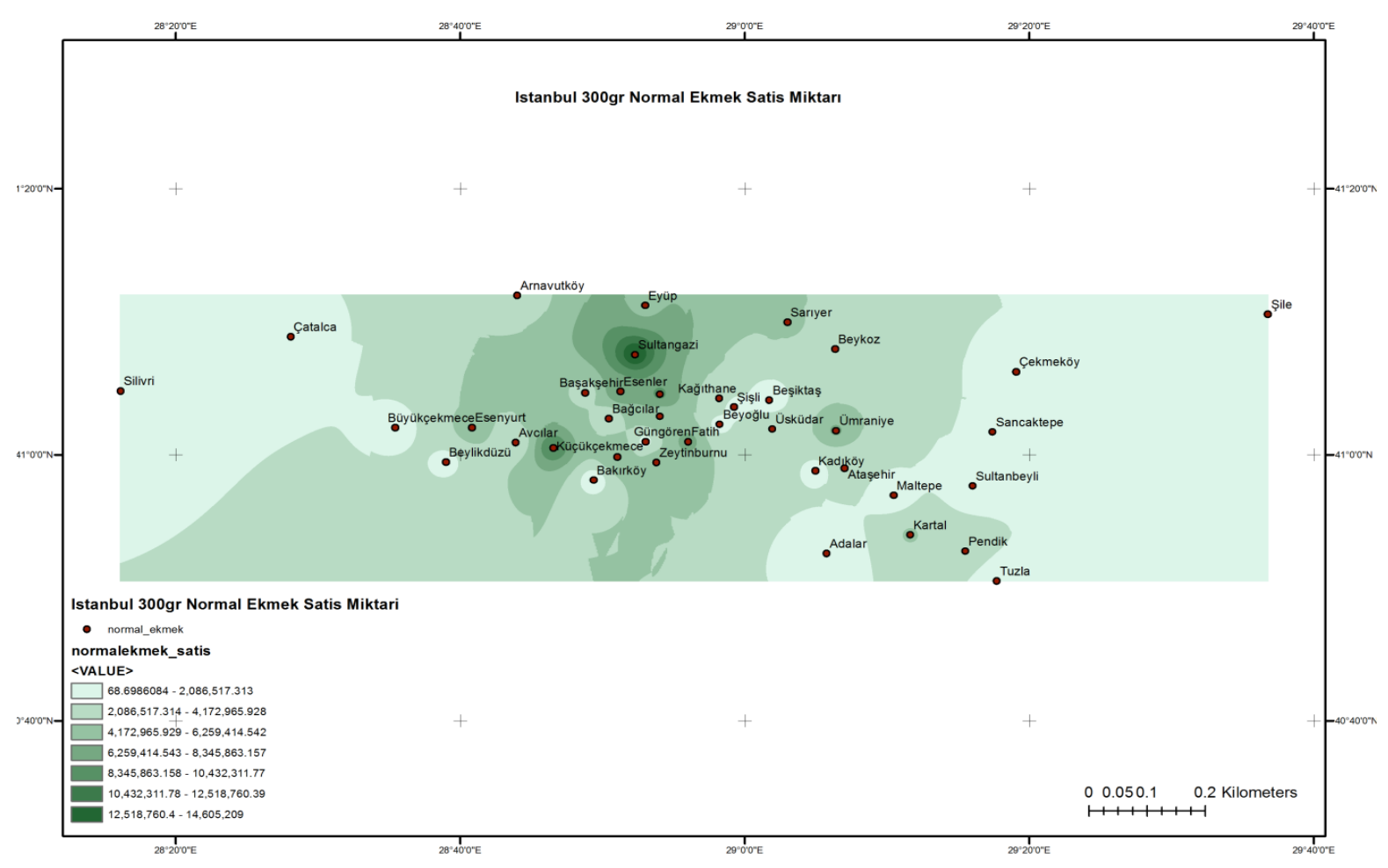

Şekil 1 Fabrikaların İstanbul genelinde normal ekmek satış yoğunluğu 
Gıda Sektöründe İstatistiksel Proses Kontrolü: Endüstriyel Ekmek Üretim Tesisi Uygulaması

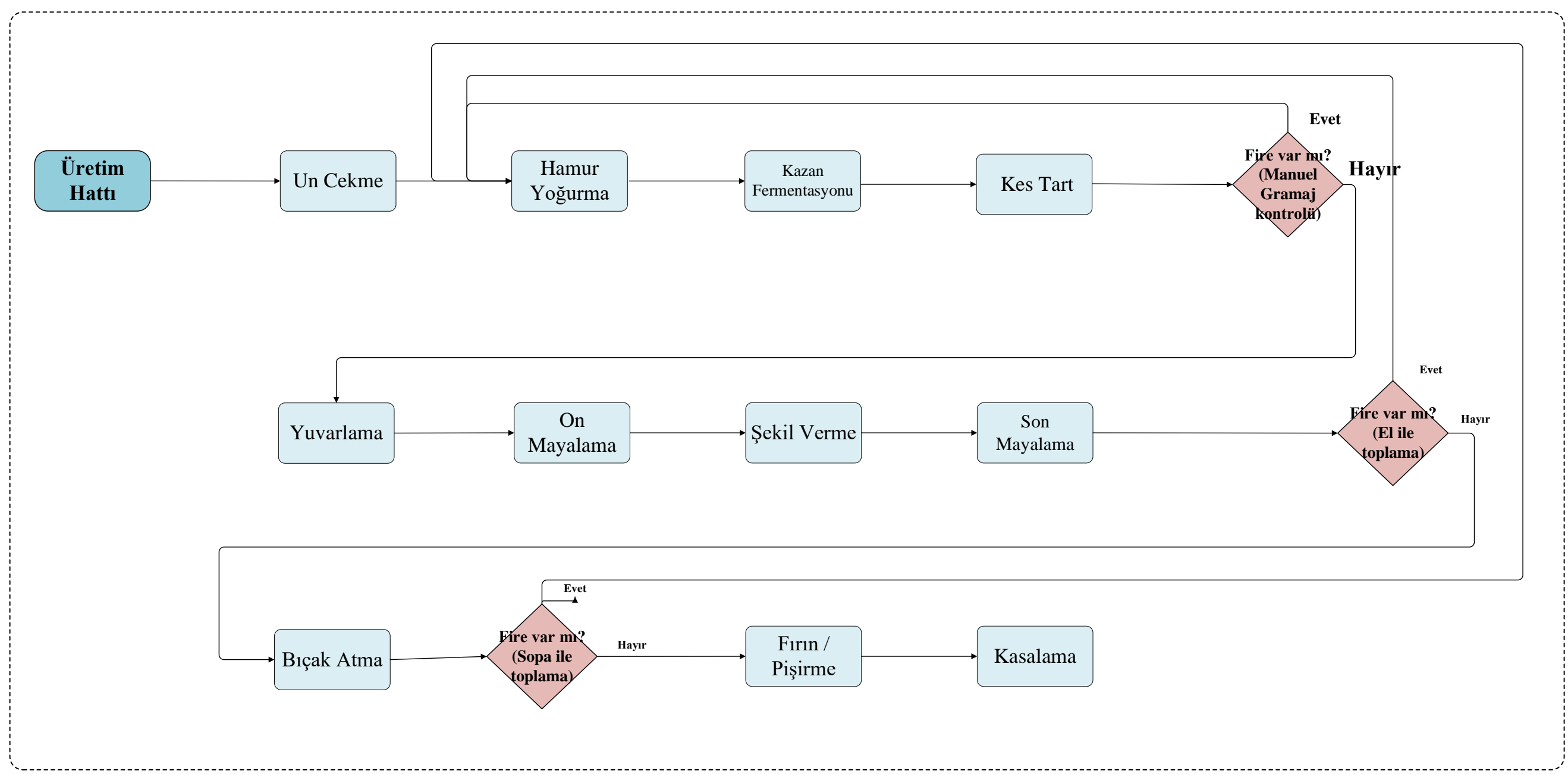

Şekil 2 Normal ekmek üretimi süreç akış şeması 


\subsection{Ekmek gramaj istatistikleri}

Ekmek gramajina ait 3 fabrikadan, kasalama prosesinden önce, pişirme prosesinden sonra normal ekmek örneklemleri alınmıştır. Örnek alma işlemi, kasalama/paketleme hattının olduğu alanda gerçekleştirilmiştir. $\mathrm{Bu}$ fabrikalardan hangi hatlardan, hangi parti büyüklüğünde ne kadar örneklem alındığ Tablo 1'de verilmiştir. Bir gruba ait belirli değişkenlerin değerleri hakkında bilgiyi özetlemek için tanımlayıcı istatistikler kullanılmıştır. Çalışmada kullanılan temel istatistikler ait temel bilgiler Tablo 2'de verilmiştir.

Tablo 1 Örneklem verileri ve fabrika bilgileri

\begin{tabular}{|c|c|c|c|c|}
\hline $\begin{array}{c}\text { Fabrika ve } \\
\text { Hatlar }\end{array}$ & Ekmek Türü & $\begin{array}{c}\text { Örneklem } \\
\text { Sayısı } \\
\end{array}$ & $\begin{array}{c}\text { Her Örneklem için Gözlem } \\
\text { Sayısı } \\
\end{array}$ & $\begin{array}{c}\text { Alınan Toplam Gözlem } \\
\text { Sayısı }\end{array}$ \\
\hline 1.Fabrika Hat 1 & $\begin{array}{c}\text { Normal Ekmek } \\
\text { 300gr }\end{array}$ & 30 & 5 & 150 \\
\hline 1.Fabrika Hat 2 & $\begin{array}{l}\text { Normal Ekmek } \\
\text { 300gr }\end{array}$ & 30 & 5 & 150 \\
\hline 1.Fabrika Hat 3 & $\begin{array}{c}\text { Normal Ekmek } \\
\text { 300gr }\end{array}$ & 30 & 5 & 150 \\
\hline 2.Fabrika Hat 1 & $\begin{array}{c}\text { Normal Ekmek } \\
300 \mathrm{gr}\end{array}$ & 30 & 5 & 150 \\
\hline 2.Fabrika Hat 2 & $\begin{array}{c}\text { Normal Ekmek } \\
300 \mathrm{gr}\end{array}$ & 30 & 5 & 150 \\
\hline 2.Fabrika Hat 3 & $\begin{array}{c}\text { Normal Ekmek } \\
300 \mathrm{gr}\end{array}$ & 30 & 5 & 150 \\
\hline 2.Fabrika Hat 4 & $\begin{array}{c}\text { Normal Ekmek } \\
300 \mathrm{gr}\end{array}$ & 30 & 5 & 150 \\
\hline 2.Fabrika Hat 5 & $\begin{array}{c}\text { Normal Ekmek } \\
300 \mathrm{gr}\end{array}$ & 30 & 5 & 150 \\
\hline 2.Fabrika Hat 6 & $\begin{array}{c}\text { Normal Ekmek } \\
300 \mathrm{gr}\end{array}$ & 30 & 5 & 150 \\
\hline 3. Fabrika Hat 1 & $\begin{array}{c}\text { Normal Ekmek } \\
300 \mathrm{gr}\end{array}$ & 30 & 5 & 150 \\
\hline
\end{tabular}

Tablo 2 Tanımlayıcı istatistik sembolleri ve tanımları

\begin{tabular}{|c|c|}
\hline $\begin{array}{l}\text { Temel } \\
\text { istatistikler }\end{array}$ & Tanım \\
\hline$N$ & Her parti için toplam gözlem sayısı \\
\hline Ortalama & Birim başına düşen ortalama gramaj (Aritmetik ortalama) \\
\hline $\begin{array}{l}\text { Ortalamanın } \\
\text { Standart Hatası }\end{array}$ & Aritmetik ortalamanın standart hatası \\
\hline Standart Sapma & Standart sapma ortalamadan sapmaların göstergesidir. \\
\hline Varyans & $\begin{array}{l}\text { Veri setinin değişimini gösteren bir değişim ölçüsüdür. Varyansı küçük olan bir partide, } \\
\text { gözlemlerin değerleri birbirlerine nispeten yakındır diye yorumlanabilir. }\end{array}$ \\
\hline $\begin{array}{l}\text { Değişim } \\
\text { Katsayısı }\end{array}$ & $\begin{array}{l}\text { Yüksek bir değişkenlik katsayısı, ortalamadan çok uzak gözlemleri yansıtır. Değişim } \\
\text { katsayısı küçük olan serilerde dağılımın aritmetik ortalama etrafında daha yoğun dağgldığı } \\
\text { anlaşılır. }\end{array}$ \\
\hline Minimum & Her parti için en küçük gözlem değeri \\
\hline$Q 1$ & $\begin{array}{l}\text { Bir serinin dörtte birlik dilimlerinin sınırlarını gösterir. Verilerin ilk \%25'i serideki en } \\
\text { küçük değerlere sahiptir. }\end{array}$ \\
\hline Medyan & Medyan, bir sayısal veri serisi sıralandığında ortada kalan sayıdır. \\
\hline Q3 & $\begin{array}{l}\text { Bir serinin dörtte üçlük dilimlerinin sınırlarını gösterir. Verilerin ilk \%75'i serideki en } \\
\text { küçük değerlere sahiptir. }\end{array}$ \\
\hline Maksimum & Her parti için en büyük gözlem değeri \\
\hline Aralık & Dağılım aralı̆̆ 1 \\
\hline$P$ dĕgeri & $\begin{array}{l}\boldsymbol{P} \text { değeri, bir karşılaştırmada "istatistiksel anlamlı fark vardır” kararı verileceği zaman } \\
\text { olası hata miktarını gösterir. Bir test sonucunda bulunan } \boldsymbol{P} \text { değeri } 0,05 \text { 'in altında bir değer } \\
\text { ise karşılaştırılan ekmek gramaj örneklemlerinin ortalamaları arasında anlamlı farklılık } \\
\text { bulunduğu anlamına gelir. }\end{array}$ \\
\hline
\end{tabular}




\section{2 Üretim hatları arası istatistiksel analiz}

$\mathrm{Bu}$ bölümde, Fabrika 1 (FB1), Fabrika 2 (FB2) ve Fabrika 3 (FB3)'ten alınan ekmek gramaj örneklemlerinin fabrikalar aras1 ve hatlar arası istatistiksel olarak aralarında bir fark var midır yok mudur test edilmiştir. FB1 ve FB2 'de 2'den fazla hat olduğu için Tek Yönlü Varyans Analizinden (ANOVA) faydalanılmıştır. Tek yönlü varyans analizi, bir faktör çatısı altında, iki yada ikiden daha fazla bağımsız grubun ortalamalarını karşılaştırmak için kullanılmaktadır.

Tablo 3 ve Tablo 4; Fabrika 1 ve Fabrika 2'deki üretim hatlarının birbiriyle ve kendi arasında ekmek gramaj ortalamaları arasındaki istatistiksel ilişki, tek yönlü varyans analizi kullanılarak \%95 güvenirlilik düzeyinde test edilerek çıkarılmıştır. ("Var" kelimesi hatlar arasında ekmek gramaj ortalamaları arasında istatistiksel olarak anlamlı bir farklılık vardır. "Yok" kelimesi ise ekmek gramaj ortalamaları arasında istatistiksel olarak anlamlı bir farklılık yoktur).

Tablo 3 FB1 normal ekmek hatlarının istatistiksel anlamda ilişkisi

\begin{tabular}{|l|l|l|l|}
\hline Ekmek & FB1 & FB1 & FB1 \\
Hatları & Hat1 & Hat2 & Hat3 \\
\hline Hat1 & - & Var & Var \\
\hline Hat2 & Var & - & Var \\
\hline Hat3 & Var & Var & - \\
\hline
\end{tabular}

Tablo 4 FB2 normal ekmek hatlarının istatistiksel anlamda ilişkisi

\begin{tabular}{|c|c|c|c|c|c|c|}
\hline $\begin{array}{l}\text { Ekmek } \\
\text { Hatları }\end{array}$ & $\begin{array}{l}\text { FB2 } \\
\text { Hat1 }\end{array}$ & $\begin{array}{l}\text { FB2 } \\
\text { Hat2 }\end{array}$ & $\begin{array}{l}\text { FB2 } \\
\text { Hat3 }\end{array}$ & $\begin{array}{l}\text { FB2 } \\
\text { Hat4 }\end{array}$ & $\begin{array}{l}\text { FB2 } \\
\text { Hat5 }\end{array}$ & $\begin{array}{c}\text { FB2 } \\
\text { Hat6 }\end{array}$ \\
\hline Hat1 & - & Var & Var & Var & Var & Var \\
\hline Hat2 & Var & - & $\underline{Y o k}$ & $\underline{Y o k}$ & Var & Var \\
\hline Hat3 & Var & Yok & - & $\overline{\text { Var }}$ & Var & Var \\
\hline Hat4 & Var & $\overline{Y o k}$ & Var & - & Var & $\underline{Y o k}$ \\
\hline Hat5 & Var & Var & Var & Var & - & $\underline{Y o k}$ \\
\hline Hat6 & Var & Var & Var & Yok & Yok & - \\
\hline
\end{tabular}

\subsubsection{Fabrika 1 (FB1) Varyans Analizi}

İlk olarak FB1 fabrikasında normal ekmek üreten Hat1, Hat2 ve Hat3 için alınan gramaj örneklemlerinin istatistiksel olarak hat bazında farklılığını analiz edilmiştir.

$\mathrm{H}_{0}$ : \%95 güvenle, Hat1, Hat2 ve Hat3 hatlarından alınan ekmek gramaj ortalamaları arasında istatistiksel olarak anlamlı bir farkl1l1k yoktur.
$\mathrm{H}_{1}$ : \%95 güvenle, Hat1, Hat2 ve Hat3 hatlarından alınan ekmek gramaj arasında istatistiksel olarak anlamlı bir farklılık vardır.

Tablo 5 ve Şekil 3 incelendiğinde FB1 HAT3 (Normal Ekmek Hattı 3) ün ortalamasının diğer gruplardan daha büyük olduğu görülmektedir. 
Tablo 5 FB1 üretim hatlarına ait örneklem bilgileri

\begin{tabular}{|l|l|l|l|l|}
\hline FB1 Üretim Hatları & N & Ortalama & Standart Sapma & 95\% CI \\
\hline HAT 1 & 150 & 305,720 & 6,260 & $(304,578 ; 306,862)$ \\
\hline HAT 2 & 150 & 299,440 & 6,381 & $(298,298 ; 300,582)$ \\
\hline HAT 3 & 150 & 319,567 & 8,482 & $(318,425 ; 320,708)$ \\
\hline
\end{tabular}

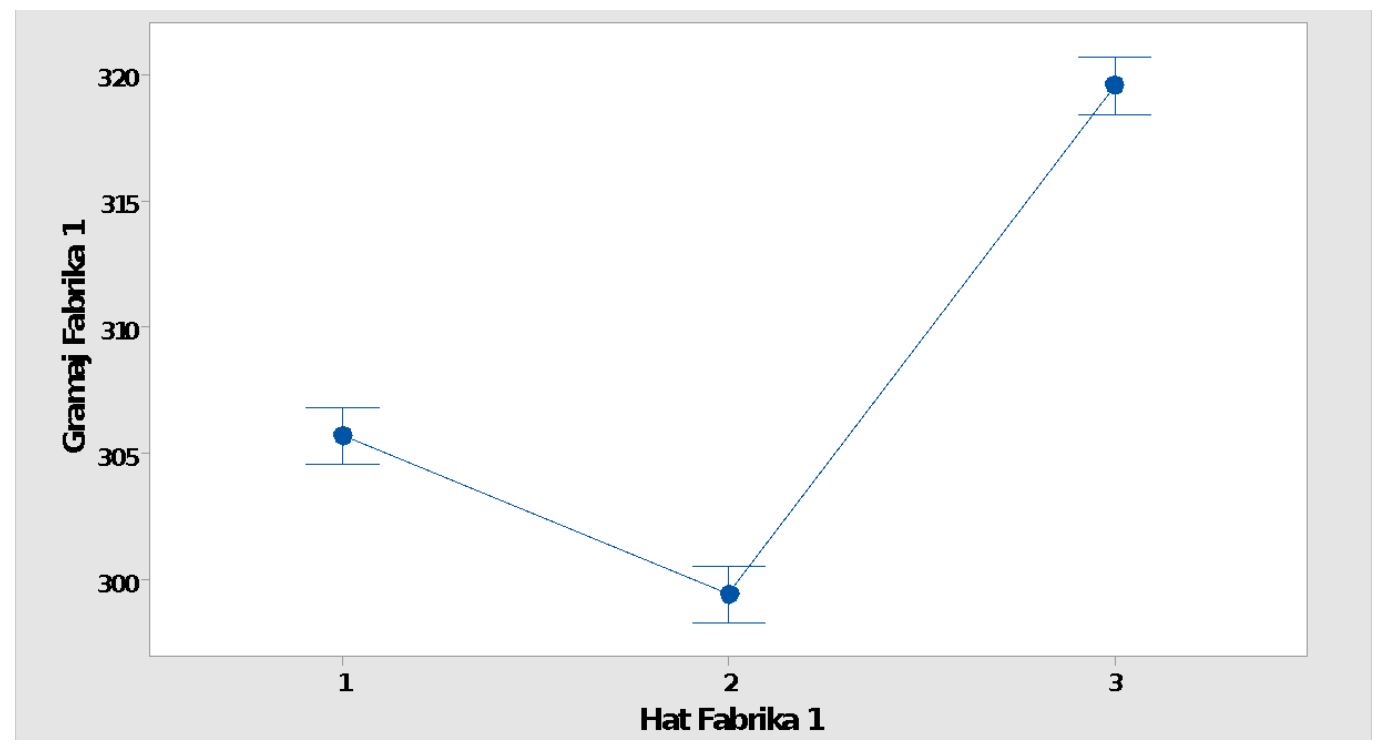

Şekil 3 Fabrika 1 için Hat1, Hat2 ve Hat3'ün normal ekmek gramaj örneklem ortalamaları

ANOVA sıfir hipotezi ile öne sürülen ikiden fazla (3 grup; HAT1=HAT2=HAT3) grubun ortalamalarının eşit olması durumu test edilmektedir. $\boldsymbol{p}$ değeri 0.05 'ten büyük olursa bu hipotez kabul edilmektedir. Eğer $\boldsymbol{p}$ değeri 0.05 'ten küçük ise bu hipotez reddedilmekte ve 3 grup arasında farklılık olduğu görülmektedir.

Tablo 6 FB1 Varyans Analizi

\begin{tabular}{|c|c|c|c|c|c|}
\hline Kaynak & $\mathbf{S d}^{*}$ & $\begin{array}{l}\text { Adj } \\
\text { SS* }\end{array}$ & Adj MS* & $\begin{array}{l}\text { F- } \\
\text { Değeri }\end{array}$ & $\begin{array}{l}\text { P- } \\
\text { Değeri }\end{array}$ \\
\hline FB1 & 2 & 31813 & 15906,3 & 314,27 & 0,000 \\
\hline Hata & 447 & 22624 & 50,6 & & \\
\hline Toplam & 449 & 54437 & & & \\
\hline
\end{tabular}

ANOVA tablosu incelendiğinde, "Sig." değeri (p-değeri) $0.000<0.05$ olduğu için tek yönlü varyans analizi için olan $\mathrm{H}_{0}$ hipotezi reddedilir. Yani " \%95 güvenle, grupların ortalamalarl arasinda istatistiksel olarak anlamlı bir farklılık vardır." denilebilir. Hangi grupların ortalamaları arasında farkl1lıklar olduğunu görmek için bir Tablo 7 incelenir. $\mathrm{Bu}$ tabloda her grubun ikişerli karşılaştırmaları yapılmış ve bu karşılaştırılan grupların ortalamaları arasındaki farklar sayısal olarak verilmiştir. Tablo incelendiğinde Hat2- Hat1, Hat3- Hat1 ve Hat3- Hat2 üretim hatlarının ekmek gramaj ortalamaları arasında anlamlı bir farklılık olduğu görülmektedir. 
Tablo 7 FB1 Tukey Testi sonuçları

\begin{tabular}{|c|c|c|c|c|c|c|}
\hline Hatlar & & $\begin{array}{l}\text { Ortalamaları } \\
\text { Arasındaki Farklar }\end{array}$ & $\begin{array}{l}\text { Std. } \\
\text { Farkı }\end{array}$ & $\begin{array}{l}95 \% \text { Güven } \\
\text { Aralığı }\end{array}$ & $\begin{array}{l}\text { T- } \\
\text { Değeri }\end{array}$ & $\begin{array}{l}\text { Düzeltilmiş } \\
\text { P-Değeri }\end{array}$ \\
\hline $\begin{array}{l}\text { Hat2 } \\
\text { Hat1 }\end{array}$ & - & $-6,280$ & 0,821 & $\begin{array}{l}(-8,203 ; \\
4,357)\end{array}$ & $-7,64$ & 0,000 \\
\hline $\begin{array}{l}\text { Hat3 } \\
\text { Hat1 }\end{array}$ & - & 13,847 & 0,821 & $\begin{array}{l}(11,924 \\
15,769)\end{array}$ & 16,86 & 0,000 \\
\hline $\begin{array}{l}\text { Hat3 } \\
\text { Hat2 }\end{array}$ & - & 20,127 & 0,821 & $\begin{array}{l}(18,204 \\
22,049)\end{array}$ & 24,50 & 0,000 \\
\hline
\end{tabular}

\subsubsection{Fabrika 2 (FB2) Varyans Analizi}

FB2 fabrikasında normal ekmek üreten Hat1, Hat2, Hat3, Hat4, Hat5 ve Hat6 için alınan gramaj örneklemlerinin istatistiksel olarak hat bazında ortalamalarının eşit olması durumu test edilmiştir. Tablo 8 ve Şekil 4 incelendiğinde, örnek ortalamalarının beklenen değer olan 300 gr. Civarında olduğu ve Fabrika 2'de üretilen normal ekmeğin gramajının Fabrika 1'e göre daha kararlı olduğu görülebilir.
Ho: \%95 güvenle, Hat1, Hat2, Hat3, Hat4, Hat5 ve Hat6 hatlarından alınan ekmek gramaj ortalamaları arasında istatistiksel olarak anlamlı bir farklılık yoktur.

$\mathrm{H}_{1}$ : \%95 güvenle, Hat1, Hat2, Hat3, Hat4, Hat5 ve Hat6 hatlarından alınan ekmek gramaj arasında istatistiksel olarak anlamlı bir farklılık vardır.

Tablo 8 FB2 üretim hatlarına ait örneklem bilgileri

\begin{tabular}{|l|l|l|l|l|}
\hline FB2 Üretim Hatları & N & Ortalama & Std. & 95\% Güven Aralı̆̆ \\
\hline $\mathbf{1}$ & 150 & 307,240 & 4,359 & $(306,216 ; 308,264)$ \\
\hline $\mathbf{2}$ & 150 & 303,600 & 6,763 & $(302,576 ; 304,624)$ \\
\hline $\mathbf{3}$ & 150 & 304,027 & 7,793 & $(303,003 ; 305,051)$ \\
\hline $\mathbf{4}$ & 150 & 302,453 & 6,405 & $(301,429 ; 303,477)$ \\
\hline $\mathbf{5}$ & 150 & 299,207 & 6,581 & $(298,183 ; 300,231)$ \\
\hline $\mathbf{6}$ & 150 & 301,287 & 5,932 & $(300,263 ; 302,311)$ \\
\hline
\end{tabular}

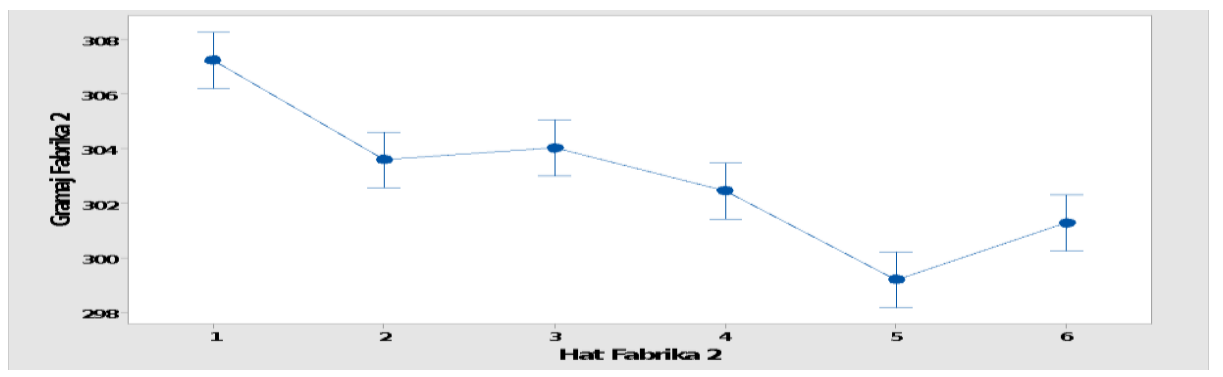

Şekil 4 Fabrika 2 için Hat1, Hat2, Hat3, Hat4, Hat5 ve Hat6'nın normal ekmek gramaj örneklem ortalamaları

ANOVA tablosu (Tablo 9) incelendiğinde, pdeğeri $0.000<0.05$ olduğu için tek yönlü varyans analizi için olan $\mathrm{H} 0$ hipotezi reddedilir, " \%95 güvenle, grupların 
ortalamaları arasinda istatistiksel olarak anlaml bir farklllk vardır." denilebilir. Hangi grupların ortalamaları arasında farkl111klar olduğunu görmek için Tablo 10 incelenir. Tabloda her grubun ikişerli karşılaştırmaları yapılmış ve bu karşılaş̧ırılan grupların ortalamaları arasındaki farklar ve $\mathrm{p}$ değeri sayısal olarak verilmiştir. sig.(p) değeri $<0.05$ ten küçük olduğu için 2-1, 3-1, 4-1, 5$1,6-1,5-2,6-2,5-3,6-3$ ve 5-4 üretim hatlarının ekmek gramaj ortalamaları arasinda anlamlı bir farklillk vardir. Ama pdeğeri > 0.05 olan 3-2, 4-2, 4-3, 6-4 ve 6-5 hatları arasında istatistiksel olarak bir farklllik yoktur.

Tablo 9 FB2 Varyans analizi.

\begin{tabular}{|l|l|l|l|l|l|}
\hline Kaynak & Sd $^{*}$ & $\begin{array}{l}\text { Adj } \\
\text { SS* }\end{array}$ & $\begin{array}{l}\text { Adj } \\
\text { MS* }\end{array}$ & $\begin{array}{l}\text { F- } \\
\text { Değeri }\end{array}$ & $\begin{array}{l}\text { P- } \\
\text { Değeri }\end{array}$ \\
\hline FB2 & 5 & 5551 & 1110,29 & 27,19 & 0,000 \\
\hline Hata & 894 & 36504 & 40,83 & & \\
\hline Toplam & 899 & 42055 & & & \\
\hline
\end{tabular}

Tablo 10 FB2 Tukey testi sonuçları

\begin{tabular}{|c|c|c|c|c|c|}
\hline Hatlar & $\begin{array}{c}\text { Ortalamaları Arasındaki } \\
\text { Farklar }\end{array}$ & $\begin{array}{c}\text { Std. } \\
\text { Farki }\end{array}$ & $\begin{array}{c}\text { 95\% Güven } \\
\text { Aralı̆̆ }\end{array}$ & $\begin{array}{c}\text { T- } \\
\text { Değeri }\end{array}$ & $\begin{array}{c}\text { Düzeltilmiş P- } \\
\text { Değeri }\end{array}$ \\
\hline $\begin{array}{c}\text { Hat2 - Hat } \\
\text { 1 }\end{array}$ & $-3,640$ & 0,738 & $(-5,743 ;-1,537)$ & $-4,93$ & 0,000 \\
\hline $\begin{array}{c}\text { Hat3 - } \\
\text { Hat1 }\end{array}$ & $-3,213$ & 0,738 & $(-5,316 ;-1,111)$ & $-4,35$ & 0,000 \\
\hline $\begin{array}{c}\text { Hat4 - } \\
\text { Hat1 }\end{array}$ & $-4,787$ & 0,738 & $(-6,889 ;-2,684)$ & $-6,49$ & 0,000 \\
\hline $\begin{array}{c}\text { Hat5 - } \\
\text { Hat1 }\end{array}$ & $-8,033$ & 0,738 & $(-10,136 ;-5,931)$ & $-10,89$ & 0,000 \\
\hline $\begin{array}{c}\text { Hat6 - } \\
\text { Hat1 }\end{array}$ & $-5,953$ & 0,738 & $(-8,056 ;-3,851)$ & $-8,07$ & 0,000 \\
\hline $\begin{array}{c}\text { Hat3 - } \\
\text { Hat2 }\end{array}$ & 0,427 & 0,738 & $(-1,676 ; 2,529)$ & 0,58 & 0,992 \\
\hline $\begin{array}{c}\text { Hat4 - } \\
\text { Hat2 }\end{array}$ & $-1,147$ & 0,738 & $(-3,249 ; 0,956)$ & $-1,55$ & 0,629 \\
\hline $\begin{array}{c}\text { Hat5 - } \\
\text { Hat2 }\end{array}$ & $-4,393$ & 0,738 & $(-6,496 ;-2,291)$ & $-5,95$ & 0,000 \\
\hline $\begin{array}{c}\text { Hat6 - } \\
\text { Hat2 }\end{array}$ & $-2,313$ & 0,738 & $(-4,416 ;-0,211)$ & $-3,14$ & 0,021 \\
\hline $\begin{array}{c}\text { Hat4 - } \\
\text { Hat3 }\end{array}$ & $-1,573$ & 0,738 & $(-3,676 ; 0,529)$ & $-2,13$ & 0,271 \\
\hline $\begin{array}{c}\text { Hat5 - } \\
\text { Hat3 }\end{array}$ & $-4,820$ & 0,738 & $(-6,923 ;-2,717)$ & $-6,53$ & 0,000 \\
\hline $\begin{array}{c}\text { Hat6 - } \\
\text { Hat3 }\end{array}$ & $-2,740$ & 0,738 & $(-4,843 ;-0,637)$ & $-3,71$ & 0,003 \\
\hline $\begin{array}{c}\text { Hat5 - } \\
\text { Hat4 }\end{array}$ & $-3,247$ & 0,738 & $(-5,349 ;-1,144)$ & $-4,40$ & 0,000 \\
\hline $\begin{array}{c}\text { Hat6 - } \\
\text { Hat4 }\end{array}$ & $-1,167$ & 0,738 & $(-3,269 ; 0,936)$ & $-1,58$ & 0,611 \\
\hline $\begin{array}{c}\text { Hat6 - } \\
\text { Hat5 }\end{array}$ & 2,080 & 0,738 & $(-0,023 ; 4,183)$ & 2,82 & 0,054 \\
\hline
\end{tabular}

Fabrika 3'de (FB3) sadece bir tane normal ekmek üretim hattı olduğu için varyans analizi yapılamamaktadir.

\subsubsection{Tüm fabrikaların normal ekmek hatlarının kıyaslanması}

FB1, FB2 ve FB3 fabrikasında normal ekmek üreten FB1 Hat1, FB1 Hat2, FB1 Hat3, FB2 Hat1, FB2 Hat2, FB2 Hat3, FB2 Hat4, FB2 Hat5, FB2 Hat6 ve FB3 Hat1 için alınan örneklemlerinin istatistiksel olarak fabrika bazında ortalamalarının eşit olması durumu test edilmiştir. 
Ho: \%95 güvenle, FB1 Hat1, FB1 Hat2, FB1 Hat3, FB2 Hat1, FB2 Hat2, FB2 Hat3, FB2 Hat4, FB2 Hat5, FB2 Hat6 ve FB3 Hatl hatlarından alınan normal ekmeğin gramaj ortalamaları arasında istatistiksel olarak anlamlı bir farklılık yoktur.

H1: \%95 güvenle, FB1 Hat1, FB1 Hat2, FB1 Hat3, FB2 Hat1, FB2 Hat2, FB2 Hat3, FB2 Hat4, FB2 Hat5, FB2 Hat6 ve FB3 Hat1 hatlarından alınan normal ekmeğin gramaj arasında istatistiksel olarak anlamlı bir farklılık vardır.

Tablo 11 incelendiğinde, Sig.(p) değeri (0.00) $<0.05$ ten küçük olduğu için FB1, FB2 ve FB3 normal ekmek üretim hatlarının gramaj ortalamaları arasinda anlamlı bir farklılık $\underline{\text { vardır. }}$. Tablo 12'de 3 fabrika için her grubun ikişerli karşılaştırmaları yapılmış ve bu karşılaştırılan grupların ortalamaları arasındaki farklar ve p-değeri sayısal olarak verilmiştir. Tablo incelendiğinde sig.(p) değeri $<0.05$ ten küçük olduğu için aşağıdaki ikili karşılaştırmalarda bazı hatların ortalamaları arasında anlamlı bir fark vardır. Örneğin Fabrika 2 Hat3 - Fabrika 1 Hat1 normal ekmek ortalamaları arasında anlamlı fark vardir.

Tablo 11 Varyans analizi

\begin{tabular}{|l|l|l|l|l|l|}
\hline Kaynak & Sd* $^{*}$ & $\begin{array}{l}\text { Adj } \\
\text { SS* }\end{array}$ & $\begin{array}{l}\text { Adj } \\
\text { MS* }^{*}\end{array}$ & $\begin{array}{l}\text { F- } \\
\text { Değeri }\end{array}$ & $\begin{array}{l}\text { P- } \\
\text { Değeri }\end{array}$ \\
\hline Hat & 9 & 45841 & 5093,49 & 102,78 & 0,000 \\
\hline Error & 1490 & 73840 & 49,56 & & \\
\hline Total & 1499 & 119681 & & &
\end{tabular}

Tablo 12 Tüm Fabrikalar için Tukey Testi Sonuçları

\begin{tabular}{|c|c|c|c|c|c|}
\hline Hatlar & $\begin{array}{c}\text { Ortalamaları Arasındaki } \\
\text { Farklar }\end{array}$ & $\begin{array}{l}\text { Std. } \\
\text { Farki }\end{array}$ & $\begin{array}{l}\text { 95\% Güven } \\
\text { Aralığı }\end{array}$ & $\begin{array}{c}\text { T- } \\
\text { Değeri }\end{array}$ & $\begin{array}{c}\text { Düzeltilmiş P- } \\
\text { Değeri }\end{array}$ \\
\hline $\begin{array}{l}\text { FB1 Hat2 - FB1 } \\
\text { Hat1 }\end{array}$ & $-6,280$ & 0,813 & $(-8,849 ;-3,711)$ & $-7,73$ & 0,000 \\
\hline $\begin{array}{l}\text { FB1 Hat3 - FB1 } \\
\text { Hat1 }\end{array}$ & 13,847 & 0,813 & $(11,277 ; 16,416)$ & 17,03 & 0,000 \\
\hline $\begin{array}{l}\text { FB3 Hat1 - FB1 } \\
\text { Hat1 }\end{array}$ & 1,520 & 0,813 & $(-1,049 ; 4,089)$ & 1,87 & 0,690 \\
\hline $\begin{array}{l}\text { FB2 Hat1 - FB1 } \\
\text { Hat1 }\end{array}$ & $-2,120$ & 0,813 & $(-4,689 ; 0,449)$ & $-2,61$ & 0,214 \\
\hline $\begin{array}{l}\text { FB2 Hat2- FB1 } \\
\text { Hat1 }\end{array}$ & $-1,693$ & 0,813 & $(-4,263 ; 0,876)$ & $-2,08$ & 0,540 \\
\hline $\begin{array}{c}\text { FB2 Hat3 - FB1 } \\
\text { Hat1 }\end{array}$ & $-3,267$ & 0,813 & $(-5,836 ;-0,697)$ & $-4,02$ & 0,002 \\
\hline $\begin{array}{l}\text { FB2 Hat4 - FB1 } \\
\text { Hat1 }\end{array}$ & $-6,513$ & 0,813 & $(-9,083 ;-3,944)$ & $-8,01$ & 0,000 \\
\hline $\begin{array}{l}\text { FB2 Hat5- FB1 } \\
\text { Hat1 }\end{array}$ & $-4,433$ & 0,813 & $(-7,003 ;-1,864)$ & $-5,45$ & 0,000 \\
\hline $\begin{array}{l}\text { FB2 Hat6- FB1 } \\
\text { Hat1 }\end{array}$ & 0,007 & 0,813 & $(-2,563 ; 2,576)$ & 0,01 & 1,000 \\
\hline $\begin{array}{l}\text { FB1 Hat4 - FB1 } \\
\text { Hat2 }\end{array}$ & 20,127 & 0,813 & $(17,557 ; 22,696)$ & 24,76 & 0,000 \\
\hline $\begin{array}{l}\text { FB3 Hat1 - FB1 } \\
\text { Hat2 }\end{array}$ & 7,800 & 0,813 & $(5,231 ; 10,369)$ & 9,60 & 0,000 \\
\hline $\begin{array}{l}\text { FB2 Hat1 - FB1 } \\
\text { Hat2 }\end{array}$ & 4,160 & 0,813 & $(1,591 ; 6,729)$ & 5,12 & 0,000 \\
\hline $\begin{array}{c}\text { FB2 Hat2 - FB1 } \\
\text { Hat2 }\end{array}$ & 4,587 & 0,813 & $(2,017 ; 7,156)$ & 5,64 & 0,000 \\
\hline $\begin{array}{c}\text { FB2 Hat3 - FB1 } \\
\text { Hat2 }\end{array}$ & 3,013 & 0,813 & $(0,444 ; 5,583)$ & 3,71 & 0,008 \\
\hline $\begin{array}{l}\text { FB2 Hat4 - FB1 } \\
\text { Hat2 }\end{array}$ & $-0,233$ & 0,813 & $(-2,803 ; 2,336)$ & $-0,29$ & 1,000 \\
\hline $\begin{array}{c}\text { FB2 Hat5 - FB1 } \\
\text { Hat2 }\end{array}$ & 1,847 & 0,813 & $(-0,723 ; 4,416)$ & 2,27 & 0,408 \\
\hline $\begin{array}{l}\text { FB2 Hat6 - FB1 } \\
\text { Hat2 }\end{array}$ & 6,287 & 0,813 & $(3,717 ; 8,856)$ & 7,73 & 0,000 \\
\hline
\end{tabular}




\begin{tabular}{|c|c|c|c|c|c|}
\hline $\begin{array}{c}\text { FB3 Hat1 - FB1 } \\
\text { Hat3 }\end{array}$ & $-12,327$ & 0,813 & $(-14,896 ;-9,757)$ & $-15,16$ & 0,000 \\
\hline $\begin{array}{c}\text { FB2 Hat1 - FB1 } \\
\text { Hat3 }\end{array}$ & $-15,967$ & 0,813 & $\begin{array}{c}(-18,536 ;- \\
13,397)\end{array}$ & $-19,64$ & 0,000 \\
\hline $\begin{array}{c}\text { FB2 Hat2- FB1 } \\
\text { Hat3 }\end{array}$ & $-15,540$ & 0,813 & $\begin{array}{c}(-18,109 ;- \\
12,971)\end{array}$ & $-19,12$ & 0,000 \\
\hline $\begin{array}{c}\text { FB2 Hat3 - FB1 } \\
\text { Hat3 }\end{array}$ & $-17,113$ & 0,813 & $\begin{array}{c}(-19,683 ;- \\
14,544)\end{array}$ & $-21,05$ & 0,000 \\
\hline $\begin{array}{c}\text { FB2 Hat4 - FB1 } \\
\text { Hat3 }\end{array}$ & $-20,360$ & 0,813 & $\begin{array}{c}(-22,929 ;- \\
17,791)\end{array}$ & $-25,05$ & 0,000 \\
\hline $\begin{array}{c}\text { FB2 Hat5 - FB1 } \\
\text { Hat3 }\end{array}$ & $-18,280$ & 0,813 & $\begin{array}{c}(-20,849 ;- \\
15,711)\end{array}$ & $-22,49$ & 0,000 \\
\hline $\begin{array}{c}\text { FB2 Hat6 - FB1 } \\
\text { Hat3 }\end{array}$ & $-13,840$ & 0,813 & $\begin{array}{c}(-16,409 ;- \\
11,271)\end{array}$ & $-17,03$ & 0,000 \\
\hline $\begin{array}{c}\text { FB2 Hat1- FB3 } \\
\text { Hat1 }\end{array}$ & $-3,640$ & 0,813 & $(-6,209 ;-1,071)$ & $-4,48$ & 0,000 \\
\hline $\begin{array}{c}\text { FB2 Hat2 - FB3 } \\
\text { Hat1 }\end{array}$ & $-3,213$ & 0,813 & $(-5,783 ;-0,644)$ & $-3,95$ & 0,003 \\
\hline $\begin{array}{c}\text { FB2 Hat3 - FB3 } \\
\text { Hat1 }\end{array}$ & $-4,787$ & 0,813 & $(-7,356 ;-2,217)$ & $-5,89$ & 0,000 \\
\hline $\begin{array}{c}\text { FB2 Hat4 - FB3 } \\
\text { Hat1 }\end{array}$ & $-8,033$ & 0,813 & $(-10,603 ;-5,464)$ & $-9,88$ & 0,000 \\
\hline $\begin{array}{c}\text { FB2 Hat5- FB3 } \\
\text { Hat1 }\end{array}$ & $-5,953$ & 0,813 & $(-8,523 ;-3,384)$ & $-7,32$ & 0,000 \\
\hline $\begin{array}{c}\text { FB2 Hat6 - FB3 } \\
\text { Hat1 }\end{array}$ & $-1,513$ & 0,813 & $(-4,083 ; 1,056)$ & $-1,86$ & 0,695 \\
\hline $\begin{array}{c}\text { FB2 Hat2- FB2 } \\
\text { Hat1 }\end{array}$ & 0,427 & 0,813 & $(-2,143 ; 2,996)$ & 0,52 & 1,000 \\
\hline $\begin{array}{c}\text { FB2 Hat3- FB2 } \\
\text { Hat1 }\end{array}$ & $-1,147$ & 0,813 & $(-3,716 ; 1,423)$ & $-1,41$ & 0,924 \\
\hline $\begin{array}{c}\text { FB2 Hat4 - FB2 } \\
\text { Hat1 }\end{array}$ & $-4,393$ & 0,813 & $(-6,963 ;-1,824)$ & $-5,40$ & 0,000 \\
\hline $\begin{array}{c}\text { FB2 Hat5 - FB2 } \\
\text { Hat1 }\end{array}$ & $-2,313$ & 0,813 & $(-4,883 ; 0,256)$ & $-2,85$ & 0,121 \\
\hline $\begin{array}{c}\text { FB2 Hat6 - FB2 } \\
\text { Hat1 }\end{array}$ & 2,127 & 0,813 & $(-0,443 ; 4,696)$ & 2,62 & 0,210 \\
\hline $\begin{array}{c}\text { FB2 Hat3 - FB2 } \\
\text { Hat2 }\end{array}$ & $-1,573$ & 0,813 & $(-4,143 ; 0,996)$ & $-1,94$ & 0,645 \\
\hline $\begin{array}{c}\text { FB2 Hat4 - FB2 } \\
\text { Hat2 }\end{array}$ & $-4,820$ & 0,813 & $(-7,389 ;-2,251)$ & $-5,93$ & 0,000 \\
\hline $\begin{array}{c}\text { FB2 Hat5 - FB2 } \\
\text { Hat2 }\end{array}$ & $-2,740$ & 0,813 & $(-5,309 ;-0,171)$ & $-3,37$ & 0,026 \\
\hline $\begin{array}{c}\text { FB2 Hat6 - FB2 } \\
\text { Hat2 }\end{array}$ & 1,700 & 0,813 & $(-0,869 ; 4,269)$ & 2,09 & 0,534 \\
\hline $\begin{array}{c}\text { FB2 Hat4 - FB2 } \\
\text { Hat3 }\end{array}$ & $-3,247$ & 0,813 & $(-5,816 ;-0,677)$ & $-3,99$ & 0,003 \\
\hline $\begin{array}{c}\text { FB2 Hat5 - FB2 } \\
\text { Hat3 }\end{array}$ & $-1,167$ & 0,813 & $(-3,736 ; 1,403)$ & $-1,44$ & 0,916 \\
\hline $\begin{array}{c}\text { FB2 Hat6 - FB2 } \\
\text { Hat3 }\end{array}$ & 3,273 & 0,813 & $(0,704 ; 5,843)$ & 4,03 & 0,002 \\
\hline $\begin{array}{c}\text { FB2 Hat5 - FB2 } \\
\text { Hat4 }\end{array}$ & 2,080 & 0,813 & $(-0,489 ; 4,649)$ & 2,56 & 0,237 \\
\hline $\begin{array}{c}\text { FB2 Hat6 - FB2 } \\
\text { Hat4 }\end{array}$ & 6,520 & 0,813 & $(3,951 ; 9,089)$ & 8,02 & 0,000 \\
\hline $\begin{array}{c}\text { FB2 Hat6 - FB2 } \\
\text { Hat5 }\end{array}$ & 4,440 & 0,813 & $(1,871 ; 7,009)$ & 5,46 & 0,000 \\
\hline
\end{tabular}

\subsection{Normal ekmeğe ait süreç kontrol şemaları}

Fabrika 1'den alınan normal ekmek gramajlarına ait sırasıyla her bir parti için temel istatistikler çıkartılmıştır (Tablo 13). Tablo 13'de görüldüğü üzere, FB1 Hat1 için 30 örneklem partisi alınmıştır. Bu hat için normal ekmek gramaj1 için 150 gözlem alınmış ve bu ekmeklerin ağırlık ortalaması 
305.72 gr'dır. Değişkenlik varyansının (39.18) ve değişkenlik katsayısının (2.05) çok yüksek olduğunu görülmektedir. Bu 150 gözlem içerisindeki en küçük değer 292 gr ve en büyük değer 320 gr'dır. Kartillere bakıldığında, Q1 ile verilerin \%25 i, 300 gr'dan küçüktür. Bu sonuçlara göre Fabrika 1'de üretilen normal ekmek hatları arasında std sapma ve gramaj farkları yüksektir. İstenilen ortalama gramaj 300 gr olmasıdır ama hatlar arasında değişkenlik fazladır.

Tablo 13 FB1 için normal ekmek gramajına ait temel istatistikler.

\begin{tabular}{lllllllllllll}
\hline Değişken & $\mathrm{N}$ & Ortalama & Ortalamanın Standart Hatası & Std & Varyans & Değişim Katsayıs1 & Minimum & Q1 & Medyan & Q3 & Maksimum Aralık \\
\hline Hat 1 & 150 & 305,72 & 0,511 & 6,26 & 39,18 & 2,05 & 292,00 & 300,0 & 307,0 & 310,0 & 320,00 & 28,0 \\
Hat 2 & 150 & 299,44 & 0,521 & 6,38 & 40,72 & 2,13 & 282,00 & 296,0 & 300,0 & 302,0 & 327,00 & 45,0 \\
Hat 3 & 150 & 319,57 & 0,693 & 8,48 & 71,94 & 2,65 & 274,00 & 316,8 & 320,5 & 324,0 & 335,00 & 61,0
\end{tabular}

Fabrika 1, Hat 1'e bakıldığına (Şekil 5); 13. Parti'deki toplam 5 gözlem değerinin örneklem ortalaması alt kontrol limitlerini aştığını görülmektedir. Süreç Kontrol altında değildir. $\bar{X}$ Kontrol şemasında UCL (Üst Kontrol Limiti) $=312.60$, LCL (Alt Kontrol Limiti) $=298.84 \quad$ ve $\quad \overline{\bar{X}} \quad$ (Orta Çizgi) $=305.72$ 'dir. " $R$ " grafiği (aralık) ise örneğin kendi içindeki aralık değerlerinin zamana bağlı değişimini yani yayılmanın zamana bağlı değişimini göstermektedir. " $R$ " kontrol şemasında kontrol limitlerini aşmadığını ve tüm testlerden geçtiğini görülmektedir. R kontrol şemasında ise UCL (Üst Kontrol Limiti)=25.23, LCL (Alt Kontrol Limiti) $=0.0$ ve $\bar{R}$ (Orta Çizgi $)=11.93$ 'tür. Fabrika 1, Hat 2'ye bakıldığına (Şekil 6); $\bar{X}$ kontrol şemasında 2. Parti, 10. Parti, 11. Parti, 14. Parti, 15. Parti, 18. Parti, 19. Parti ve 20. Parti 'deki toplam 5 gözlem değerinin örneklem ortalaması üst ve alt kontrol limitlerini aştı̆̆ görülmektedir. Süreç kontrol altında değildir. Bu kontrol limitleri haricine çıkan numunelerin fazlaca olması problemin mevcut olduğunu göstermektedir. $\bar{X}$ kontrol şemasında UCL (Üst Kontrol Limiti) $=304.73$, LCL (Alt Kontrol Limiti) $=294.15$ ve $\overline{\bar{X}}$ (Merkez Çizgi)=299.44'tür. "R" şemasında 10. ve 30. Parti hariç diğer partilerin kontrol limitlerini aşmadığını görmekteyiz. R kontrol şemasinda ise UCL (Üst Kontrol Limiti $)=19.38$, LCL (Alt Kontrol Limiti) $=0.0$ ve $\bar{R}$ (Merkez Çizgi) $=9.17$ 'dir. Fabrika 1 , Hat 3'e bakıldığına (Şekil 7); $\bar{X}$ şemasında 5. Parti, 14. Parti ve 20. Parti 'deki toplam gözlem değerlerinin örneklem ortalaması üst ve alt kontrol limitlerini aştığı görülmektedir. Süreç kontrol altında değildir. $\bar{X}$ kontrol şemasında UCL (Üst Kontrol Limiti) $=328.33$, LCL (Alt Kontrol Limiti) $=310.80$ ve $\overline{\bar{X}}$ (Merkez Çizgi)=319.57'dir. "R" grafiğinde 14. Parti ve 16. Parti hariç diğer partilerin kontrol limitlerini aşmadığını görülmektedir. $\mathrm{R}$ kontrol şemasinda ise UCL (Üst Kontrol Limiti $)=32.14$, LCL (Alt Kontrol Limiti $)=0.0$ ve $\bar{R}$ (Merkez Çizgi) $=15.2$ 'dir. 


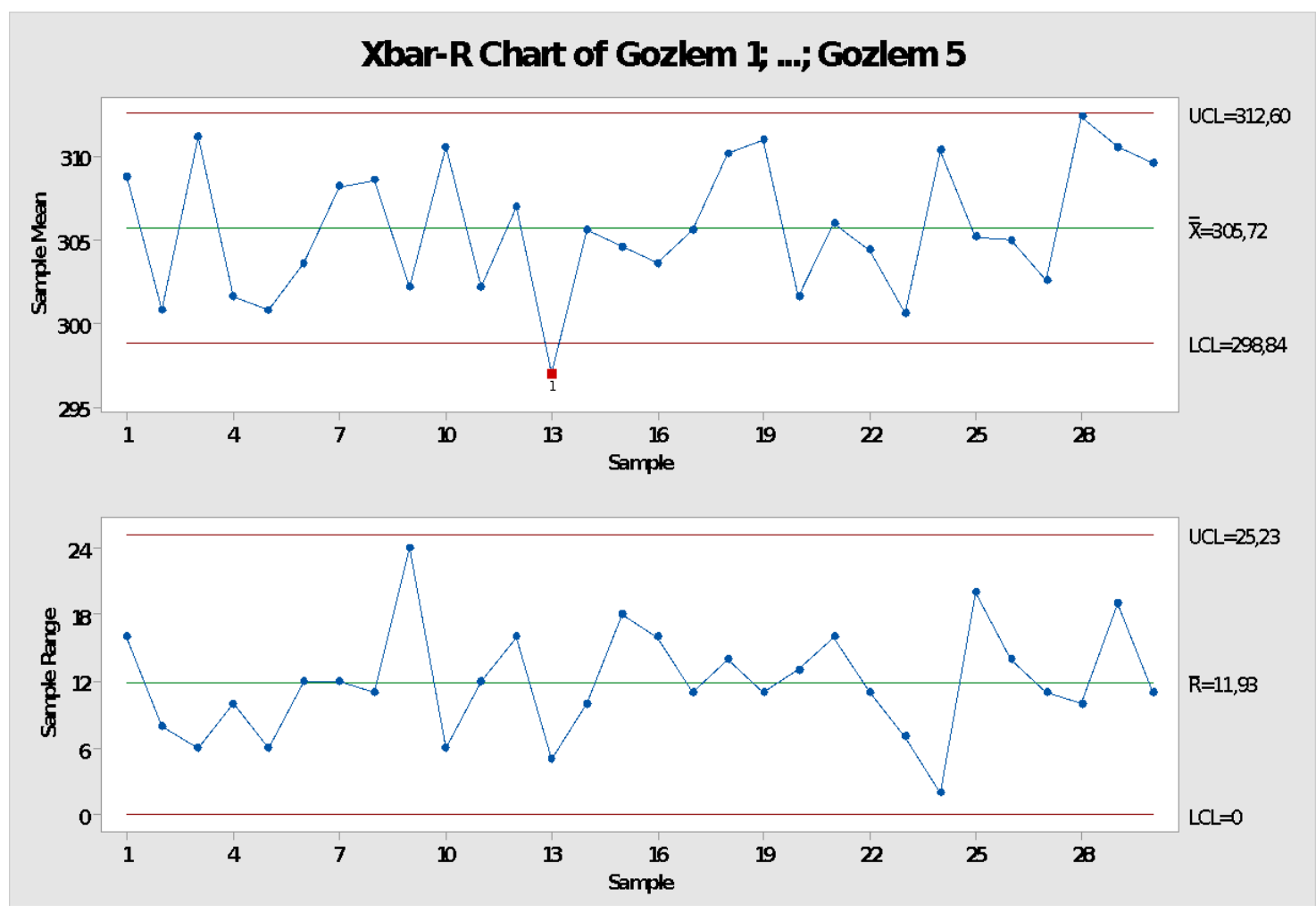

Şekil 5 FB1 Hat1 normal ekmek için $\bar{X}$-R kontrol şeması

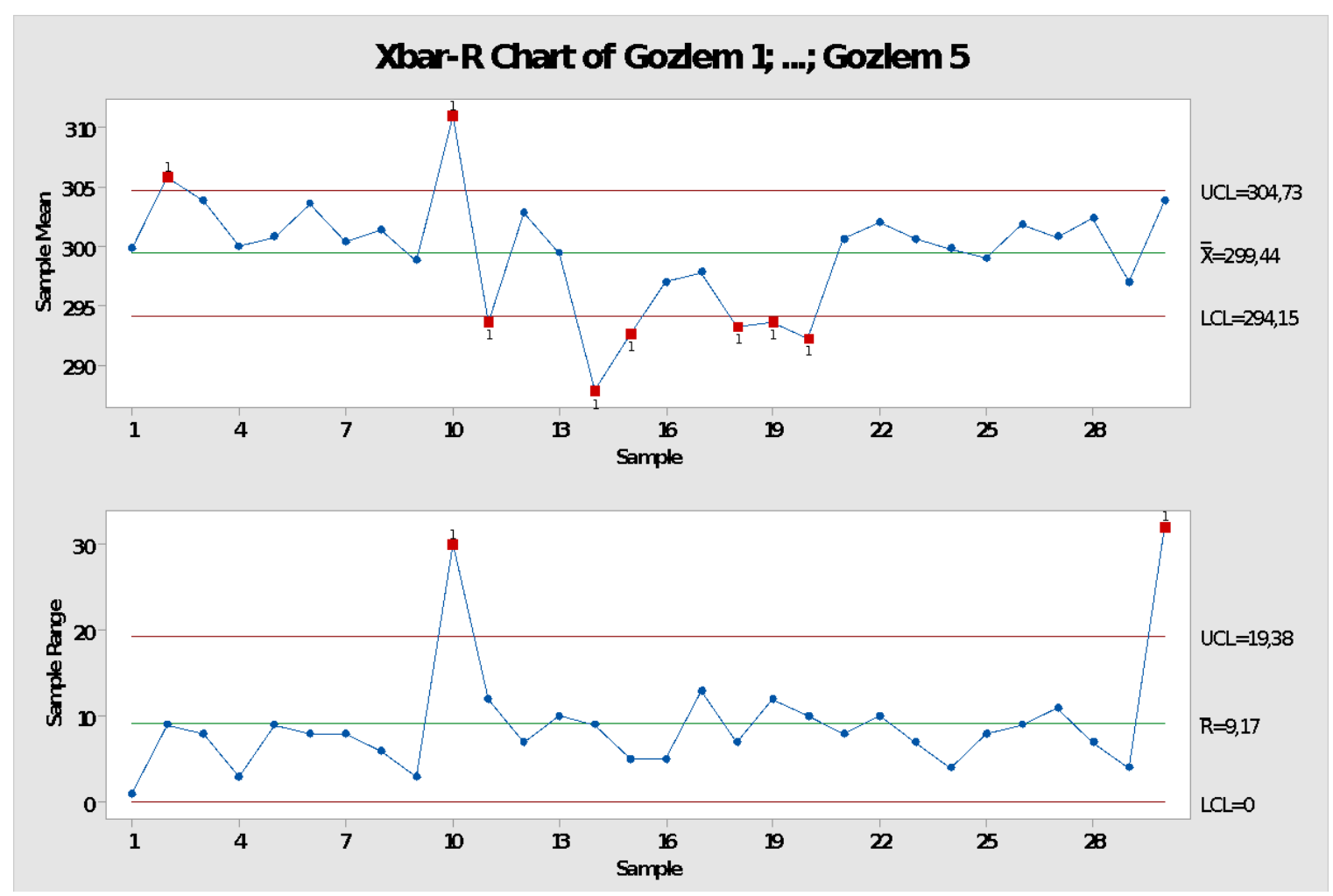

Şekil 6 FB1 Hat2 normal ekmek için $\bar{X}$-R kontrol şeması 


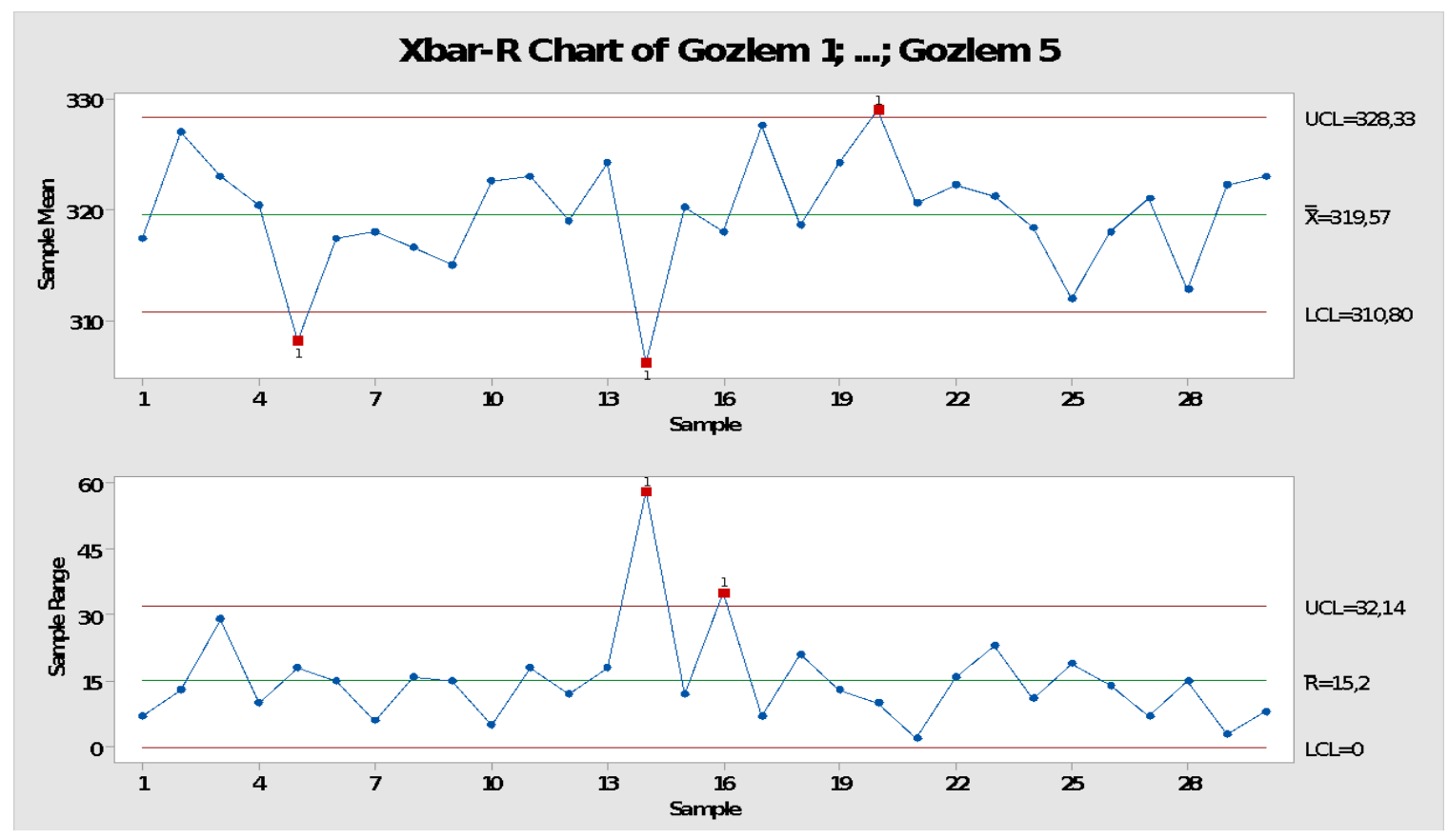

Şekil 7 FB1 Hat3 normal ekmek için $\bar{X}$-R kontrol şeması

Tablo 14. FB2 için normal ekmek gramajına ait temel istatistikler.

\begin{tabular}{llllllllllllll}
\hline Değişken & $\mathrm{N}$ & Ortalama & $\begin{array}{l}\text { Ortalamanın } \\
\text { Hatas1 }\end{array}$ & Standart & Std & Varyans & $\begin{array}{l}\text { Değişim } \\
\text { Katsayı1 } 1\end{array}$ & Minimum & Q1 & Medyan & Q3 & Maksimum & Aralık \\
\hline Hat 1 & 150 & 307,24 & 0,356 & & 4,36 & 19,00 & 1,42 & 293,00 & 304,75 & 308,00 & 310,00 & 317,00 & 24,00 \\
Hat 2 & 150 & 303,60 & 0,552 & & 6,76 & 45,73 & 2,23 & 278,00 & 300,00 & 304,00 & 309,00 & 315,00 & 37,00 \\
Hat 3 & 150 & 304,03 & 0,636 & & 7,79 & 60,74 & 2,56 & 280,00 & 300,00 & 304,00 & 308,25 & 338,00 & 58,00 \\
Hat 4 & 150 & 302,45 & 0,523 & 6,41 & 41,03 & 2,12 & 273,00 & 300,00 & 303,00 & 307,00 & 318,00 & 45,00 \\
Hat 5 & 150 & 299,21 & 0,537 & 6,58 & 43,31 & 2,20 & 274,00 & 296,00 & 300,00 & 303,00 & 314,00 & 40,00 \\
Hat 6 & 150 & 301,29 & 0,484 & 5,93 & 35,19 & 1,97 & 286,00 & 297,00 & 301,00 & 305,00 & 317,00 & 31,00 \\
\hline
\end{tabular}

Tablo 14 ise Fabrika 2'nin normal ekmek üretim hatları arasındaki temel istatistik bilgileri göstermektedir. $\mathrm{Bu}$ sonuçlara göre Fabrika 2'de üretilen normal ekmek hatları arasında std sapma ve gramaj farkları Fabrika 1 göre daha düşüktür ve hatlar arasında değişkenlik daha azdır.

Fabrika 2, Hat 1'e bakıldığına (Şekil 8); $\bar{X}$ kontrol şemasında 2. Parti 'deki toplam gözlem değerlerinin örneklem ortalaması üst kontrol limitini aştığı görülmektedir. Süreç kontrol altında değildir. UCL $=312.41, \mathrm{LCL}$ $=302.07$ ve $\overline{\bar{X}}=307.24$ 'tür. " $\mathrm{R}$ " şemasında ise süreç kontrol altındadır. UCL (Üst Kontrol Limiti) $=18.96$, LCL (Alt Kontrol Limiti) $=0$ ve $\bar{R}$ (Merkez Çizgi) $=8.97$ 'dir. Fabrika 2 , Hat 2'ye bakıldığına (Şekil 9); $\bar{X}$ kontrol şemasındaki 29. parti hariç bütün noktalar sınırlar içerisindedir ama proses kontrol altında değildir. UCL $=311.60, \mathrm{LCL}=295.60$ ve $\overline{\bar{X}}=303.6$ 'dır. "R" şemasında ise 11. parti hariç tüm partiler aynı şekilde kontrol limitlerinin içerisindedir. UCL (Üst Kontrol Limiti $)=29.32$, LCL (Alt Kontrol Limiti) $=0$ ve $\bar{R}$ (Merkez Çizgi) $=13.87^{\prime}$ dir. 


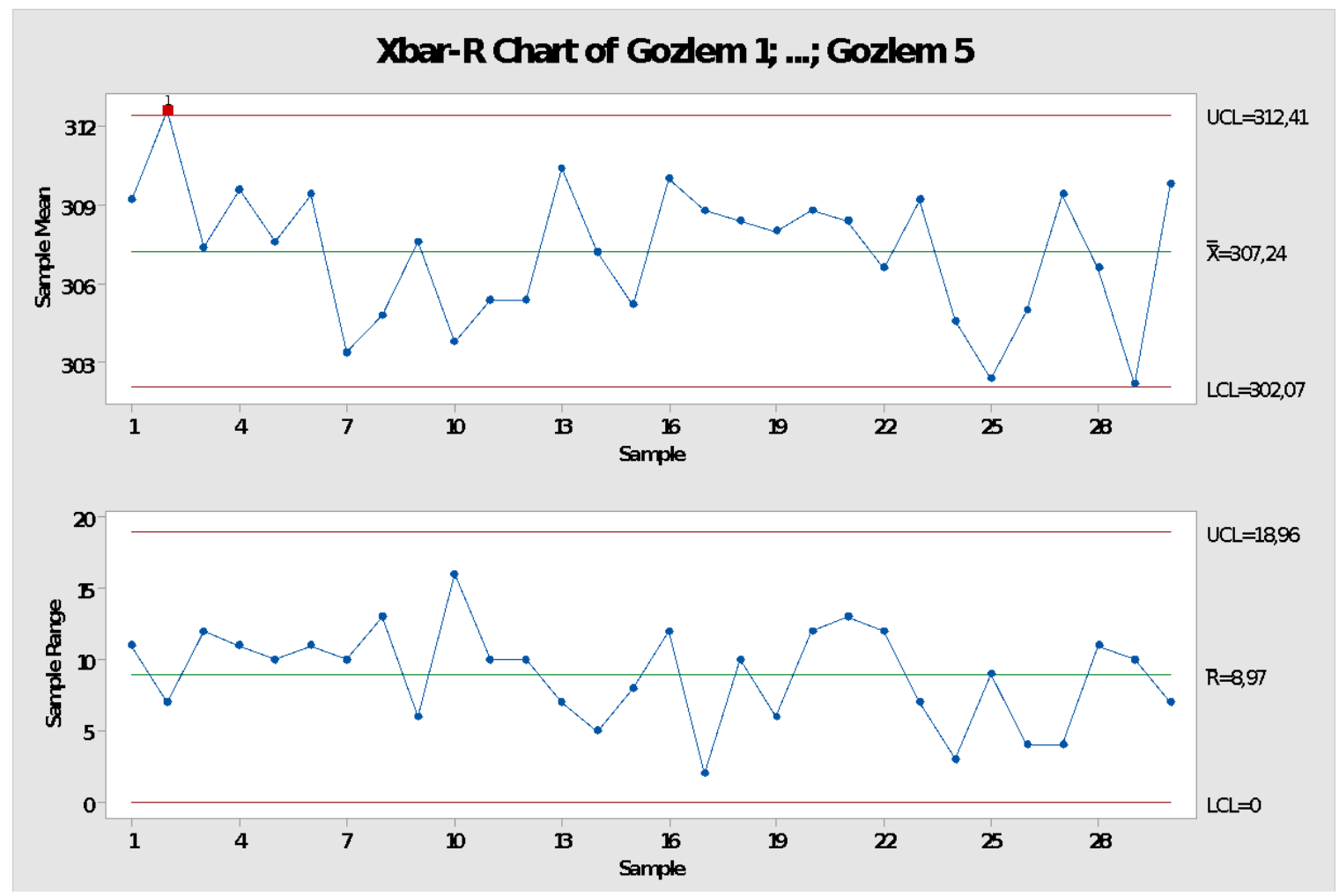

Şekil 8 FB2 hat1 normal ekmek için $\bar{X}$-R kontrol şemas1

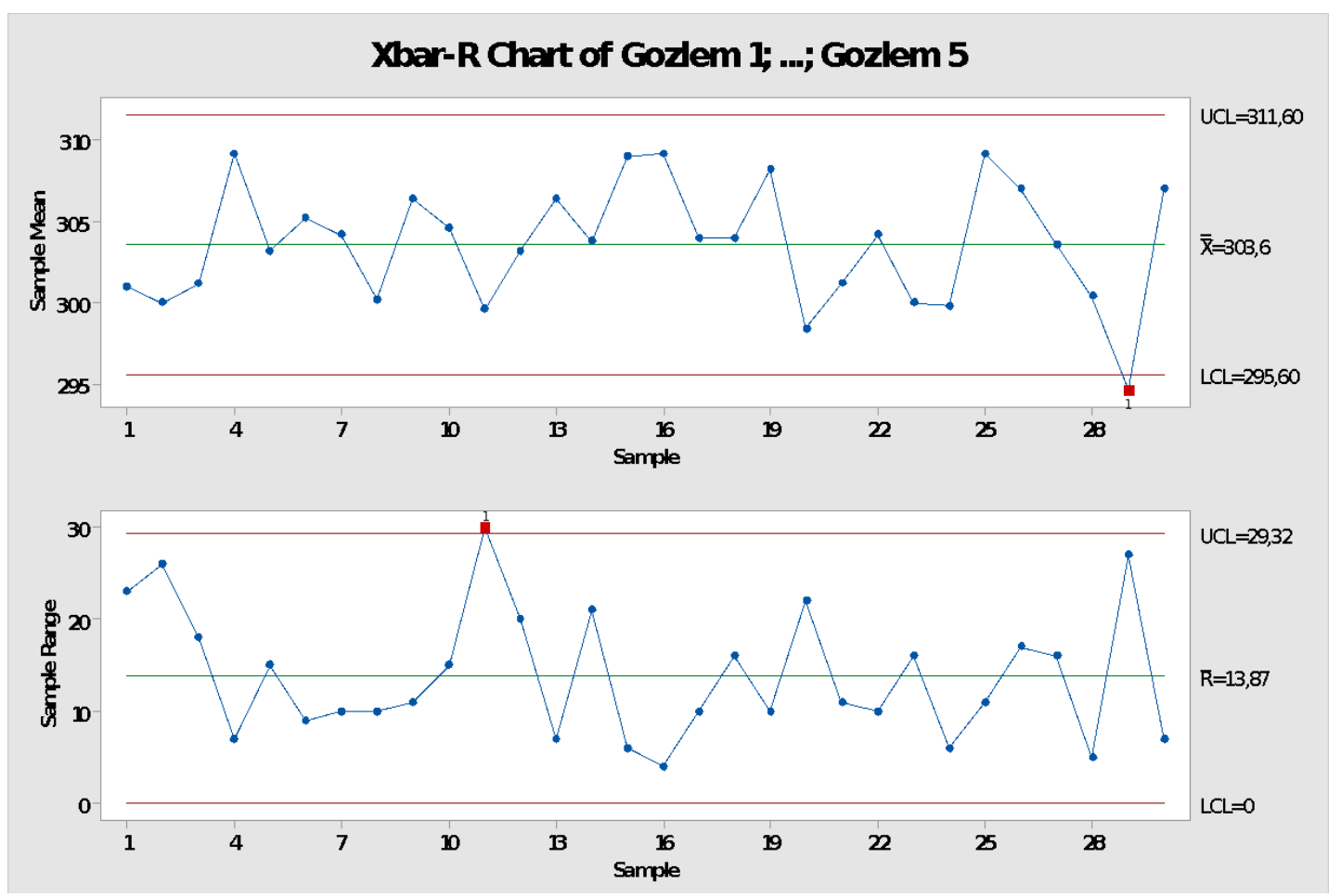

Şekil 9. FB2 hat2 normal ekmek için $\bar{X}$-R kontrol şeması

Fabrika 2, Hat 3'e bakıldığına (Şekil 10); $\bar{X}$ ortalaması alt ve üst kontrol limitlerini kontrol şemasında 1., 23. ve 25. parti 'deki aşmaktadır. Süreç kontrol altında değildir. toplam gözlem değerlerinin örneklem UCL $=312.72, \quad$ LCL $=295.34$ ve $\overline{\bar{X}}$ 
$=304.03$ 'tür. " $R$ " grafiğinde ise 3. Parti süreç kontrol altında değildir. $\mathrm{R}$ kontrol şemasında UCL (Üst Kontrol Limiti)=31.86, LCL (Alt Kontrol Limiti) $=0$ ve $\bar{R} \quad$ (Merkez Çizgi) $=15.77$ 'dir. Fabrika 2, Hat 4'e bakıldığına (Şekil 11); $\bar{X}$ kontrol şemasında 2. ve 19. parti 'deki toplam gözlem değerlerinin örneklem ortalaması alt ve üst kontrol limitlerini aştı̆̆ görülmektedir. Süreç kontrol altında değildir. "R" grafiğinde ise 2. parti üst kontrol limiti dışındadır. Fabrika 2, Hat 5'e bakıldığına (Şekil 12); $\bar{X}$ kontrol şemasında
3., 10., ve 19. parti 'deki toplam gözlem değerlerinin örneklem ortalaması alt ve üst kontrol limitlerini aşmaktadır. Süreç kontrol altında değildir. " $R$ " grafiğinde ise 20. parti üst kontrol limiti dışındadır. Fabrika 2, Hat 6'ya bakıldığına (Şekil 13); $\bar{X}$ kontrol şemasında 1., 8., 17., 24., 25., 26. ve 30. parti 'deki toplam gözlem değerlerinin örneklem ortalaması alt ve üst kontrol limitlerini aştığ1 görülmektedir. Süreç kontrol altında değildir. " $R$ " grafiğinde ise tüm parti gözlem değerleri alt ve üst kontrol limiti içindedir.

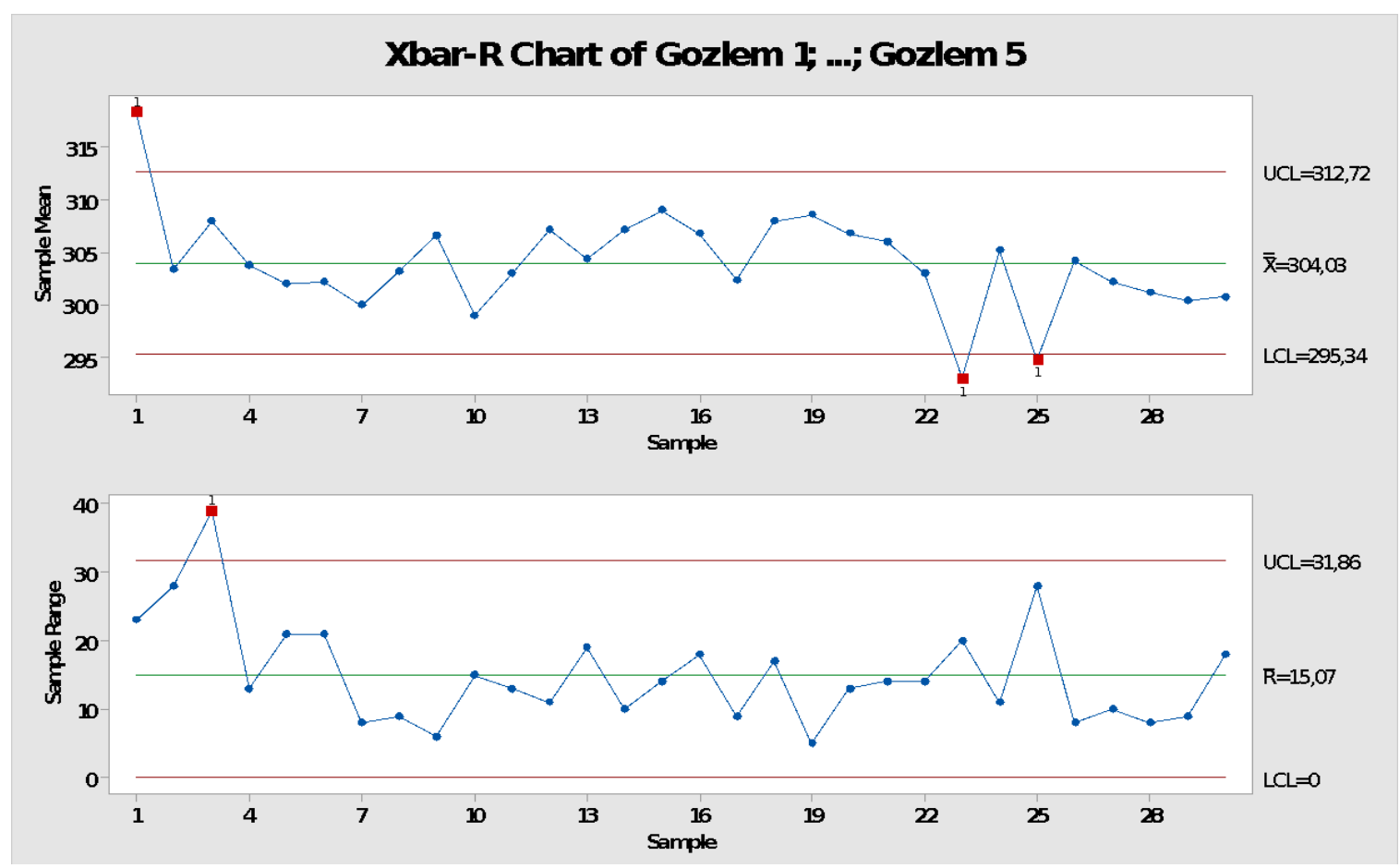

Şekil 10. FB2 hat3 normal ekmek için $\bar{X}$-R kontrol şeması 


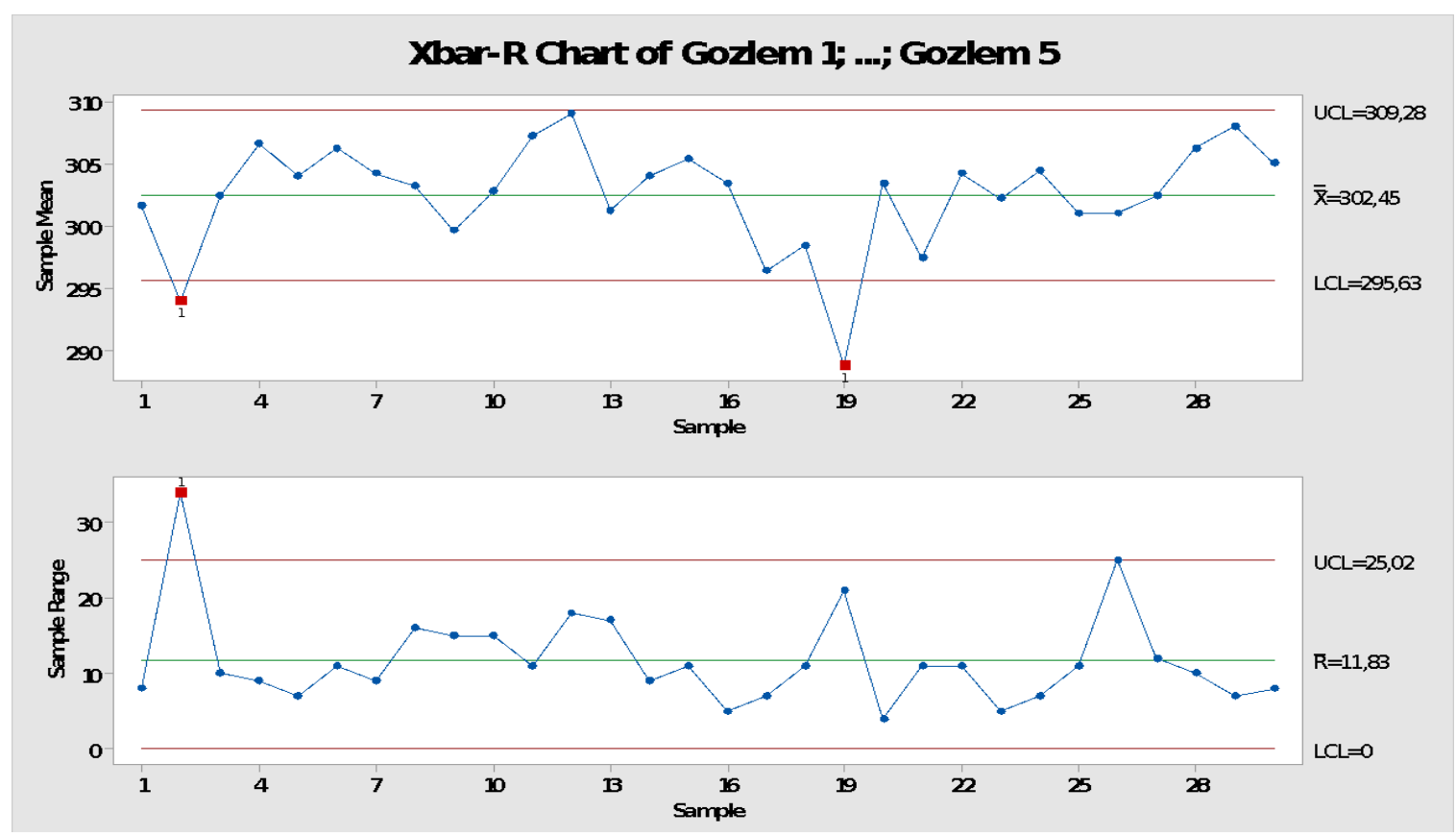

Şekil 11. FB2 hat4 normal ekmek için $\bar{X}$-R kontrol şemas1

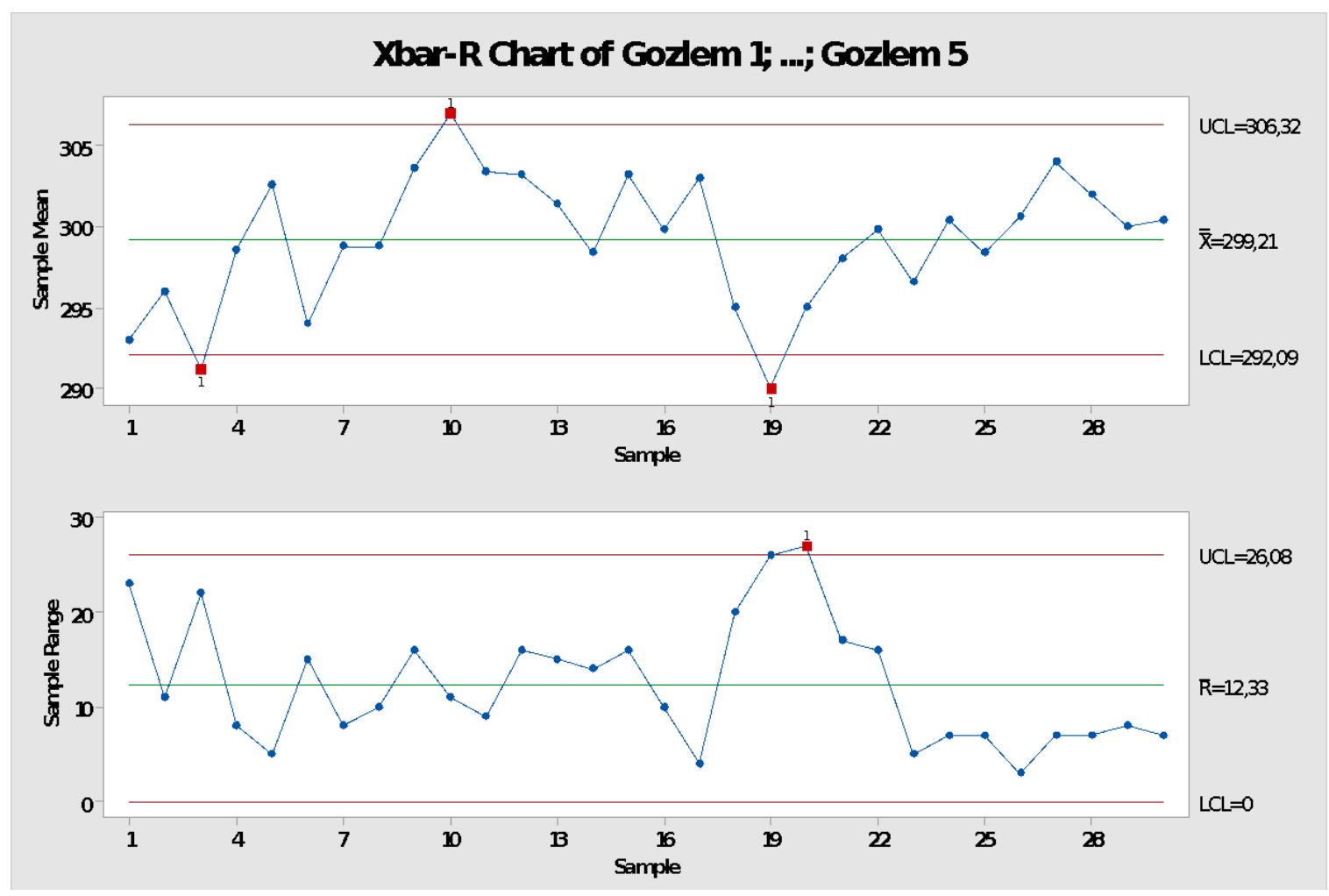

Şekil 12. FB2 hat5 normal ekmek için $\bar{X}$-R kontrol şeması 


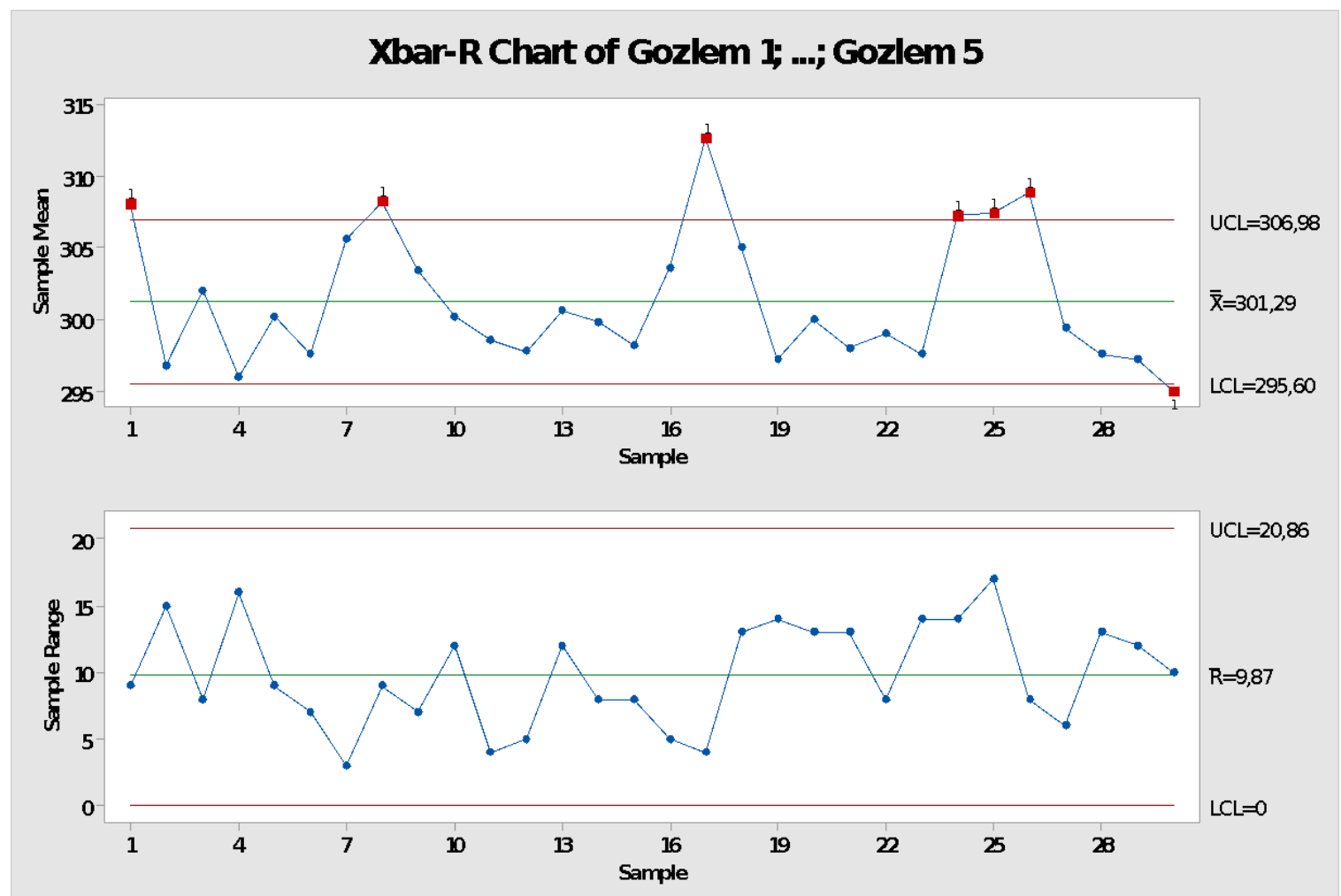

Şekil 13. FB2 hat6 normal ekmek için $\bar{X}$-R kontrol şeması

Fabrika 3, Hat 1'e bakıldı̆̆ına (Şekil 14); $\bar{X}=299.33$ ve $\overline{\bar{X}}=306.33$ 'dir. "R" şemasında ise kontrol şemasında 10. Parti 'deki toplam gözlem değerlerinin örneklem ortalaması üst kontrol limitini aştığını görülmektedir. Süreç 25. Parti kontrol limitini aşmaktadır. UCL (Üst Kontrol Limiti) $=25.66$, LCL (Alt Kontrol kontrol altında değildir. UCL $=313.33, \mathrm{LCL}$

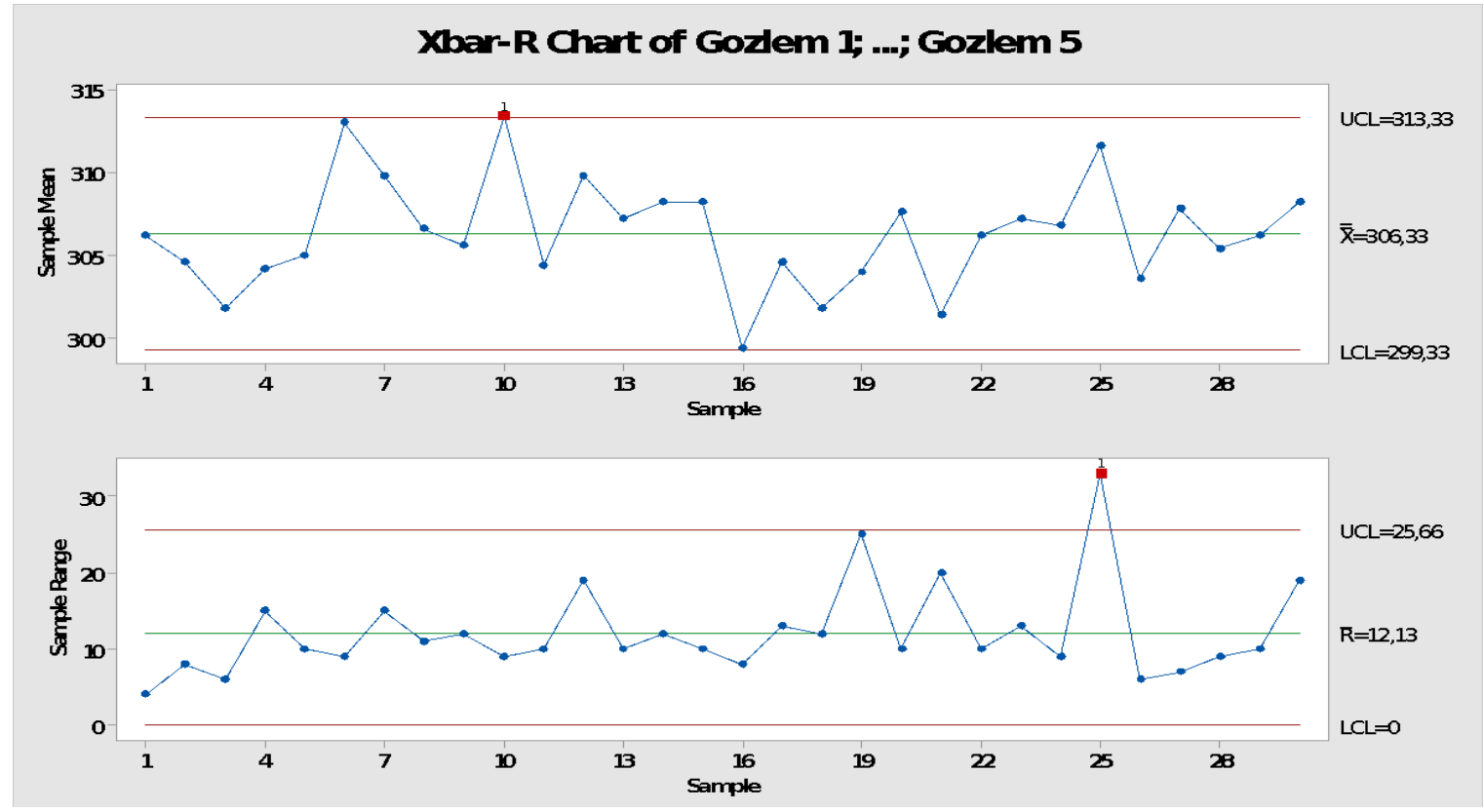

Şekil 14. FB3 hat1 normal ekmek için $\bar{X}$-R kontrol şeması 


\section{Bulgular ve Tartışma}

Üç ekmek fabrikasında normal ekmek (300 gr) üretebilen 10 hat incelenmiş ve kalite karakteristiği olarak pişmiş ekmek gramaj1 seçilmiştir. Her hat için 5'erli 30 örneklem, pişirme prosesinden hemen sonra alınmış ve kalibrasyonu yapılmış tartı aracılığ 1 ile tartılmıştır. Sonuç olarak fabrikalar arası ekmek gramajları arasında anlamlı bir fark olduğu tespit edilmiştir. Özelikle Fabrika 1'de (FB1) bazı hatlarda normal ekmek gramajları belirtilen alt ve üst kontrol limitlerinin dışındadır. İçinde olsa bile gramajlar arasındaki değişkenlik çok fazladır. Tüm fabrikalardan alınan örneklerin gramaj ortalaması "Türk Gıda Kodeksi Ekmek ve Ekmek Çeşitleri Tebliği'nde" ambalajsız piyasaya sürülen ekmeklere ait resmi değerlere uymaktadır. Fakat gramaj ortalamalarının özellikle Fabrika 1'de, beklenen değer olan 300 gramdan fazla olduğu görülmektedir. $\mathrm{Bu}$ da hammadde maliyetlerini arttırmakta ve ekmeğin birim maliyetini yükseltmektedir. $\mathrm{Bu}$ nedenle işletmede, mevcut ortalamanın düşürülmesi yönünde çalışmalar yapılarak süreç kontrol araçlarından faydalanılmıştır.

Ekmekte gramaj olarak oluşan farklılığın sebeplerinden biri, mayalanan hamurun yaşayan bir organizma olması ve fiziksel ve kimyasal özelliklerinin sürekli değişmesi olarak tespit edilmiştir. Bunun yanı sıra ekmekte kullanılan beyaz unun sürekli farklı özelliklerde geliyor olması da bir diğer sebep olarak tespit edilmiştir. Çalışmaya konu olan tesislerin günlük üretim kapasiteleri dikkate alındığında tek bir tedarikçi ile çalışmak neredeyse mümkün olmamaktadır. Hatta neredeyse Türkiye'nin her noktasından beyaz un tedarik edildiği söylenebilir. Bu durumda ise hammadde değişkenleri, kısmen kontrol edilemeyen değişkenler olmaktadır.
Dolayısıyla bu değişkenlerin kontrol edilemediği varsayılarak, süreçteki iyileştirmelerde diğer faktörlerin üzerine gidilmiştir. Yapılan araştırmalarla bu farkın sebebinin hamur kesme (kestart) makinesinden kaynaklandığ Kestart ayarları s1kı kontrol edilerek ve küçük bir yatırımla Kestart sürecinden hemen sonra $\% 100$ gramaj kontrolüne geçilerek, pişmiş ekmek gramajlarının beklenen değer olan 300 grama düşmesi sağlanmıştır.

Bunun yanı sıra;

- Fabrika 2'de (FB2) üretilen ekmek gramaj olarak beklenen değere yakın olmasına rağmen, diğer fabrikalara göre düşük kapasite kullanım oranına sahiptir.

- $\quad$ Üretim hatlarında kusurlu ekmek oranın çok yüksek olması ve bu yüzden fazla iş gücü ile yükselen kontrol maliyetleri tespit edilmiştir.

- $\quad$ Makine bakımlarının düzenli yapılmamasından kaynaklı üretimde sıklıkla durmaların meydana geldiği gözlenmiştir. $\mathrm{Bu}$ yüzden, bakım periyotları düzenli hale getirilmelidir.

Üç fabrikada öne çıkan en önemli problemlerden biri de yapışık ekmek oranın fazla olmasıdır. Hata kaynağı araştırılmış ve Şekil verme - dökücüler prosesi hatanın başlangıcı olarak tespit edilmiştir. $\mathrm{Bu}$ proseslerin makinelerinin bakımlarında bir problem olduğu kanısına varılmıştır.

Çalışma kapsamında her ne kadar maliyetlere direk etkisi ve yasal sınırlamalar düşünülerek sadece pişmiş ekmek gramajı dikkate alınsa da, ileriki çalışmalarda farklı kalite karakteristikleri de dikkate alınarak kalite kontrol süreçleri uygulanabilir. 


\section{Kaynaklar}

Arslan, V. 2017. "Bakır Konsantre Tesislerinde Kontrol Kartlarının Ve Çok Boyutlu Ölçekleme Analizinin Uygulanması" Çukurova Üniversitesi Mühendislik-Mimarlık Fakültesi Dergisi, 32 (1), 99-108. Do1: 10.21605/Cukurovaummfd.310063

Baray, Ş. A. 2006. "A Process Control Chart Based On Uncertainty Measurement", Sigma, 2.

Baskan, Ş., (1997), "İstatistiksel Kalite Kontrolü”, Ege Üniversitesi Basımevi, İzmir.

Çolak, M, Uçurum, M , Çınar, M, Atıcı, Ü . 2018. "Application Of Fuzzy Statistical Process Control For A Manufacturing Of Gg25 Gray Cast Iron Material”. Ömer Halisdemir Üniversitesi Mühendislik Bilimleri Dergisi, 7 (1), 427-437. Do1: 10.28948/Ngumuh.387316

Doğan, İ., \& Doğan, N. 2019. "EWMA Kontrol Çizelgeleri ve Sağlik Alanında Kullanımına Genel Bir Bakış". Turkiye Klinikleri Journal of Biostatistics, 11(1).

Dweiri, F., Khan, S. A., \& Shamsuzzaman, M. 2015. "The use of statistical process control techniques in the web application products ". International Journal of Industrial and Systems Engineering, 20(1), 69-83.

Elevli, S , Behdioğlu, S . 2006. "İstatistiksel Proses Kontrolü Teknikleri İle Kömür Kalitesindeki Değişkenliğin Belirlenmesi”, Bilimsel Madencilik Dergisi, 45 (3), 19-26.

Ertuğrul, İ., \& Özçil, A. 2015.” Kalite kontrol grafiklerinden "Shewart, Cusum ve Ewma" nın bir üretim işletmesinde uygulanması". Karamanoğlu Mehmetbey Universitesi Sosyal Ve Ekonomik Araştırmalar Dergisi, 2015(1), 14-26

Ertuğrul, İ., \& Karakaşoğlu, N. 2006. "Kalite Kontrolde Örneklem Büyüklüğünün Değişken Olması Durumunda P Kontrol Şemalarının Oluşturulması", İstanbul Ticaret Üniversitesi Fen Bilimleri Dergisi, 5(10), 6580.

Ertuğrul, İ., (2004), “Toplam Kalite Kontrol Ve Teknikleri”, Ekin Kitabevi, Bursa.
Fu, X., Wang, R. F., \& Dong, Z. Y. 2017. "Application Of A Shewhart Control Chart To Monitor Clean Ash During Coal Preparation", International Journal of Mineral Processing, 158, 45-54.

He, Q. P., \& Wang, J. 2018. "Statistical process monitoring as a big data analytics tool for smart manufacturing". Journal of Process Control, 67, 35-43.

Heizer, J. H., \& Render, B. (2017). "Üretim Yönetimi- Sürdürülebilirlik Ve Tedarik Zinciri Yönetimi, Çev., Prof. Dr. Umut Rıfat Tuzkaya (11. Bask1)" Palme Yayıncılık, Ankara.

Kasa, H. 1982. "Kalite Kontrolünün Anlamı Ve Kalite Kontrolünde İstatistiğin Önemi", KTÜ Orman Fakültesi Dergisi, 5(1), 153-163.

Lim, S. A. H., Antony, J., \& Albliwi, S. 2014. "Statistical Process Control (Spc) in The Food Industry-A Systematic Review And Future Research Agenda", Trends In Food Science \& Technology, 37(2), 137-151.

Maraş, S., \& Arslan, H. 2018. "Düz dişlilerdeki aşınma ve kırık diş hatalarının tespit edilmesinde titreşim verileri kullanılarak istatistiksel proses kontrol uygulaması". Sakarya University Journal of Science, 22(2), 181-191.

Montgomery, D. C. (2009). "Introduction To Statistical Quality Control”. John Wiley \& Sons.

Özdamar, İ. 2007. "Orman Ürünleri Endüstrisinde İstatistiksel Kalite Kontrol: Yonga Levha Üretiminde Bir Çalışma", Türkiye Ormancllık Dergisi, 8(1), 79-91.

Rowlands, H., \& Wang, L. R. 2000. "An Approach Of Fuzzy Logic Evaluation And Control İn Spc." Quality And Reliability Engineering International, 16(2), 91-98.

Sales, R. F., Vitale, R., de Lima, S. M., Pimentel, M. F., Stragevitch, L., \& Ferrer, A. 2016. "Multivariate statistical process control charts for batch monitoring of transesterification reactions for biodiesel production based on near-infrared 
spectroscopy". Computers \& Chemical Engineering, 94, 343-353.

Soysal, H., \& Boran, S. 2015. "Bulanık X-R Diyagramları Kullanılarak Bulanık Süreç Yeterlilik Analizi" Sakarya University Journal Of Science, 19(1), 15-26.

Şengül, Ü., \& Şengül, A. B. 2018. "Bir İmalat İşletmesinde İstatistiksel Kalite Kontrol Grafiklerinin Uygulanmas1: SHEWHART, CUSUM, EWMA". ICPESS 2018 PROCEEDINGS Volume 2: Economic Studies, 425.

Yatkın, A., (2003), "Toplam Kalite Yönetimi”, Nobel Yayın Dă̆ıtım, Ankara.

Y1ldırım, H., \& Karaca, E. 2013. Üretim Sürecinde İstatistiksel Proses Kontrol (İpk) Uygulamaları Ve Elektronik Sektöründe Bir İnceleme. Öneri Dergisi, 10(39), 77-87.

Y1lmaz, F., \& Ersöz, T. 2017. "Kalitenin İyileştirilmesi Amacıyla İstatistiksel Kalite Kontrol Yöntemlerinin Kullanılması Üzerine Havacılık ve Uzay Sektöründe Bir Uygulama". Gaziosmanpaşa Bilimsel Araştırma Dergisi, 7(3), 159-172.

Zeyveli, M. Ve Selalmaz, E. 2008. "İstatistiksel Proses Kontrol Tekniklerinin Zincir İmalatı Yapan Bir İşletmede Uygulanması". Doğu Anadolu Bölgesi Araştırmaları.6:(3), 36-45. 